\title{
Digital Transformation Models for the I4.0 Transition: Lessons from the Change Management Literature
}

\author{
Nicola Bellantuono ${ }^{1}\left(\mathbb{D}\right.$, Angela Nuzzi ${ }^{2, *}$, Pierpaolo Pontrandolfo $^{2}\left(\mathbb{D}\right.$ and Barbara Scozzi ${ }^{2} \mathbb{D}$ \\ 1 Department of Agriculture, Food, Natural Resources and Engineering, University of Foggia, Via Napoli 25, \\ 71121 Foggia, FG, Italy; nicola.bellantuono@unifg.it \\ 2 Politecnico di Bari, Department of Mechanics, Mathematics \& Management, Via Orabona 4, \\ 70126 Bari, BA, Italy; pierpaolo.pontrandolfo@poliba.it (P.P.); barbara.scozzi@poliba.it (B.S.) \\ * Correspondence: angela.nuzzi@poliba.it
}

check for updates

Citation: Bellantuono, N.; Nuzzi, A.; Pontrandolfo, P.; Scozzi, B. Digital Transformation Models for the I4.0 Transition: Lessons from the Change Management Literature. Sustainability 2021, 13, 12941. https://doi.org/ $10.3390 /$ su132312941

Academic Editor: António Abreu

Received: 15 October 2021

Accepted: 17 November 2021

Published: 23 November 2021

Publisher's Note: MDPI stays neutral with regard to jurisdictional claims in published maps and institutional affiliations.

Copyright: (c) 2021 by the authors. Licensee MDPI, Basel, Switzerland. This article is an open access article distributed under the terms and conditions of the Creative Commons Attribution (CC BY) license (https:/ / creativecommons.org/licenses/by/ $4.0 /)$.

\begin{abstract}
The growing diffusion of digital technologies, especially in production systems, is leading to a new industrial paradigm, named Industry 4.0 (I4.0), which involves disruptive changes in the way companies organize production and create value. Organizations willing to seize the opportunities of I4.0 must thus innovate their processes and business models. The challenges that companies must face for the transition towards I4.0 paradigm are not trivial. Several digital transformation models and roadmaps have been lately proposed in the literature to support companies in such a transition. The literature on change management stresses that about $70 \%$ of change initiatives-independently of the aim-fail to achieve their goals due to the implementation of transformation programs that are affected by well-known mistakes or neglect some relevant aspects, such as lack of management support, lack of clearly defined and achievable objectives and poor communication. This paper investigates whether and to what extent the existing digital transformation models (DTMs) and roadmaps for I4.0 transition consider the lessons learnt in the field of change management. To this aim, a Systematic Literature Review to identify existing models and roadmaps is carried out. The results obtained by the review are discussed under the lens of the change-management literature. Based on that, the shortcomings and weaknesses of existing DTMs are pinpointed. Extant DTMs mainly focus on digital transformation initiatives carried out in manufacturing companies; they do not cover all the phases of the digital transformation process but rather focus on the definition of the I4.0 vision, strategy and roadmap. Little attention is devoted to the implementation and consolidation of digital change. Change management lessons are considered to a limited extent, based on which, some suggestions for better dealing with digital transformation initiatives are discussed. The paper contributes to advancing knowledge on models and approaches to support organizations in managing digital transformation. The identification of change management activities that a digital transformation initiative should involve as well as the suggestions on how to effectively deal with it can be used by managers to successfully lead the I4.0 transition journey in their organizations.
\end{abstract}

Keywords: change management; digital transition; Industry 4.0; systematic literature review

\section{Introduction}

The growing diffusion of digital technologies, especially in production systems, is leading to a new industrial paradigm, usually named Industry 4.0 (I4.0) [1]. At the core of I4.0 there are the implementation of cyber-physical systems (CPS) for industrial production, i.e., networks of microcomputers, sensors and actuators embedded in materials, machines or products that are connected along the value chain [2], and the availability of sophisticated systems to process and analyse big data in real time. Simulation, augmented reality, system integration, cloud computing, cybersecurity and additive manufacturing are other wellknown I4.0 enabling technologies [3].

All these technologies significantly extend production and consumption possibilities and represent a disruptive technological change. More specifically, I4.0 yields new value 
propositions for highly customized or differentiated products, well-synchronized productservice combinations, and value-added services. I4.0 is indeed a technology-enabled paradigm, which is deeply changing the way companies organize their processes and create value for customers. Companies are increasingly aware that digital technologies enable completely new business models and lead to the reconfiguring of the structure of all sectors, leaving out those companies that will not be able to adapt to the change. It is therefore essential for companies to innovate and re-think their business models [4,5], as well as to innovate their processes and products to seize the challenges and growth opportunities generated by the new digital technologies.

Organizations willing to exploit the opportunities and potential of the I4.0 paradigm must manage a transition from a current state to another, characterized by a higher level of digitization. As about $70 \%$ of change initiatives-independently of the aim-fail to achieve their goals [6,7], the transition towards I4.0 is complex and risky. Generally, failures are due to employee resistance, lack of clearly defined and achievable objectives, scarce management support and commitment and poor communication [8]. The transition towards I4.0 is indeed a complex process that goes beyond the mere implementation of technologies and involves all aspects of the organization.

In the last years, many scholars investigated the I4.0 paradigm from different perspectives; however, extant literature mainly focuses on technological aspects; less attention is devoted to the managerial and organizational aspects associated with digital transformation [9]. Bordeleau et al. [10], for example, argue that no frameworks and models adequately support managers and organizations in all the phases of the digital transformation process and call for more structured approaches to manage the transition towards the I4.0 paradigm.

The goal of this study is to investigate whether and to what extent the existing digital transformation models and roadmaps for the I4.0 transition consider the lessons learnt in the field of change management, a well-known approach developed to successfully manage change initiatives. To this aim, a systematic literature review is conducted to identify the digital transformation models (DTMs) developed to manage the transition towards I4.0 paradigm. The results are then analysed under the lens of the change management literature. To do so, we review and compare the main change management models and identify the set of activities to be included in any transformation initiative. The activities are then contextualized to the case of the I4.0 transition and used, together with other dimensions of analysis (i.e., involved stakeholders, focus, theoretical approach, development activities, test) to make a comparison among the DTMs retrieved from the systematic review. Based on this, the shortcomings and weaknesses of existing DTMs are pinpointed. Finally, suggestions to improve DTMs and recommendations to better deal with digital transformation in the I4.0 paradigm are provided.

The paper contributes to advancing the knowledge of models and approaches to support organizations in the management of digital transformations. The description and comparison of existing DTMs as well as the recommendations provided to better deal with a digital transformation initiative can be used by managers to successfully lead the digital transformation of their organizations.

The paper is structured as follows. After an introduction on change management and the identification of the set of activities to be included in any transformation initiative, in Section 3 the methodology adopted to conduct the systematic literature review is presented; Section 4 illustrates the results of the review; the identified models are then analysed and compared in Section 5. Some suggestions and recommendations for developing an effective digital transformation model are discussed in Section 6. Finally, in the Conclusions, the main implications of the study are summarized, and future research avenues are drawn.

\section{Change Management: Main Models and Salient Activities}

Any digital transformation initiative towards I 4.0 can be viewed as a change initiative, namely a process of transition from a current state, characterized by a certain level of 
digitization, to a future state, characterized by a higher digitization level. Accordingly, in the paper, change management is adopted as the methodological lens through which to analyse the DTMs proposed in the literature. Below, the most well-known change management models are described and examined in order to identify the set of activities to be included in any transformation initiative.

\subsection{Change Management Models}

As the pace of global, economic, and technological development makes change an inevitable feature of organizational life [11,12], organizations are increasingly requiring change management skills [13]. Change management is a structured approach to facilitating a transition from a current state (where the organisation is now) to a future state (where the organisation wants to be) [6]. It is the process of renewing an organization's direction, structure, and capabilities to serve the ever-changing needs of external and internal customers [14]. Change management also refers to the process and tools for supporting people in the transition [15]. The most well-known change management models are described and synthetized in Table 1.

Table 1. Overview of change management models.

\begin{tabular}{|c|c|c|c|}
\hline $\begin{array}{c}\text { Kurt Lewin's Change } \\
\text { Management Model [16] }\end{array}$ & Kotter's 8 Step Change Model [17] & $\begin{array}{l}\text { GE's Change Acceleration Process } \\
\text { (CAP) }[18,19]\end{array}$ & $\begin{array}{l}\text { Prosci 3-Phase Change Management Process } \\
\qquad[15,20]\end{array}$ \\
\hline \multirow{3}{*}{ Unfreeze } & \multirow[b]{2}{*}{ establish a sense of urgency } & \multicolumn{2}{|r|}{ Prepare for change: } \\
\hline & & lead the change & $\begin{array}{ll}- & \text { define change management strategy } \\
- & \text { prepare change management team } \\
- & \text { develop a sponsorship model }\end{array}$ \\
\hline & build a powerful guiding coalition & create a shared need & \multirow{5}{*}{$\begin{array}{l}\text { Manage the change: } \\
-\quad \text { develop change management plans } \\
-\quad \text { take action and implement plans }\end{array}$} \\
\hline \multirow{4}{*}{ Change } & create a shared vision & shape a vision & \\
\hline & communicate the vision & mobilize commitment & \\
\hline & empower others to act on the vision & \multirow{2}{*}{ make change last } & \\
\hline & plan for and create short-term wins & & \\
\hline \multirow{3}{*}{ Refreeze } & $\begin{array}{l}\text { consolidate improvements and } \\
\text { produce still more change }\end{array}$ & monitor the process & \multirow{3}{*}{$\begin{array}{l}\text { Reinforce the change: } \\
-\quad \text { collect and analyse feedbacks } \\
-\quad \text { diagnose gaps and manage resistance } \\
-\quad \text { implement corrective actions and } \\
\quad \text { celebrate success }\end{array}$} \\
\hline & & & \\
\hline & institutionalize new approaches & change systems and structures & \\
\hline
\end{tabular}

Kurt Lewin's Change Management Model [16] is a "three-step model" that is considered the precursor of change management models. The basic concept is that changes imply new behaviours, thus, before introducing changes in a given organization, the members must abandon old behaviours. In this sense, the three steps of the model can be described as follows:

1. Unfreeze. At the beginning, members of the organization become aware of the need for change and the reason that makes it necessary; the equilibrium which supports existing behaviours and attitudes modifies: the inherent threats that people may associate to change and the need to motivate those that will be affected should be considered in this step.

2. Change. The organization's, department's or individual's behaviour is shifted to a new level. That involves intervening in the system to develop new behaviours, values, and attitudes through changes in organizational structures and processes; as the resistance from employees may begin to emerge, it is important that the organization leaders clarify to all members, directly or indirectly involved, the reasons of change, the nature of the change and the benefits that are expected from it.

3. Refreeze. In this step the organization is stabilized into a new state of equilibrium; the new procedures and behaviours introduced in the previous steps are consolidated and incorporated into the organization. Individuals feel confident and comfortable with the new ways of working. 
Kotter's 8 Step Change Model [17] is one of the most used change management models; it encompasses eight steps to guide organizations in the implementation of successful changes:

1. Establish a sense of urgency. In the first step, the organization realizes the need for change and leadership must be able to explain to other members the urgent need to introduce changes; this first step is critical for increasing organization awareness of the need of change, therefore an examination of the market and competitors, as well as the identification and discussion of potential threats and opportunities, should be carried out.

2. Build a powerful guiding coalition. Building a team that have enough power to lead the change effort.

3. Create a shared vision. The guiding coalition develops a vision which clarifies the direction in which an organization needs to move. Without a sensible vision, a transformation effort can easily dissolve into a list of confusing and incompatible projects that might move the organization in the wrong direction. Eventually, a strategy for achieving that vision is also developed to better define the change goals and timing of implementation.

4. Communicate the vision. The guiding coalition must effectively communicate vision and strategies to all members of the organization; this phase is critical to prevent resistance to change.

5. Empower others to act on the vision. Communicating vision and strategy is not sufficient to involve people in the change process; the guiding coalition must remove obstacles to change by identifying people who are most reluctant to change, trying to understand their reasons, and encouraging their active participation in the change process.

6. Plan for and create short-term wins. Short-term wins (also known as quick wins) are results that can be obtained in a short time and that have an immediate impact. Identifying and implementing them show that the change is going in the right direction, allowing individuals who are more reluctant to change to be further involved, and helping the guiding coalition to test the vision against real conditions.

7. Consolidate improvements and produce still more change. Kotter argues that many change projects fail because victory is declared too early; the organization should consolidate their obtained results and, at the same time, evaluate the possibility of introducing further changes to continuously improve those already implemented.

8. Institutionalize new approaches. To make possible the starting of new successful changes' processes, it is essential that the implemented changes become part of the organization; to this aim, it is useful to ensure constant communication of the changes taking place and the successes achieved, and to institutionalize the organizational figures responsible for guiding the change processes.

GE's Change Acceleration Process (CAP) [18,19]. In the 1990s, General Electric (GE) under the direction of Jack Welch commissioned a team of consultants to study the best practices of change management; the result of these studies was crystallized in the so-called Change Acceleration Process (CAP).

The team highlighted that the implementation of high-quality technical solutions is not always a guarantee of the success of a change initiative; the failure of a change initiative occurs when most of the organization's effort are dedicated to the technical aspects of change rather than paying attention to people that are affected by the change. This concept is summarized in a simple equation $E=Q A$, meaning that the effectiveness $(E)$ of any initiative is equal to the product of the quality $(Q)$ of the technical strategy and the acceptance $(A)$ of that strategy; in other words, to successfully manage a change, paying attention to the people side of the equation is as important as the technical side.

The Change Acceleration Process includes seven steps:

1. Lead change: Identification of a strong and committed leadership that is in charge of the change initiative. 
2. Create a shared need: leadership clearly defines the reason for change and shares it with all stakeholders involved in the change initiative.

3. Shape a vision: leadership should articulate a clear and legitimate vision of the world after the change initiative. The end-state must be described into observable and measurable terms, and vision must be shared with all stakeholders.

4. Mobilize commitment: creation of a sense of commitment and involvement of all people interested by the change.

5. Make change last: the implementation should start with pilot projects. The successes and knowledge gained can be used for other initiatives; in this step also the factors that are helping change and those that are hindering it should be identified.

6. Monitor the process: measurement of progresses and detection of the problems.

7. Changing systems and structures: after the implementation, organizational structure should be realigned to the new situation to make change permanent.

Prosci 3-Phase Change Management Process $[15,20]$. Prosci, a global consulting team founded in 1994 and focused exclusively on change management, argues that the success of a change management initiative requires the integration of individual and organizational change management.

To support people through change, Prosci provides the so-called ADKAR model: the acronym stands for the (a)wareness of the need for change, the (d)esire to support the change, (k)nowledge of how to change, the (a)bility to implement desired skills and behaviours and the (r)einforcement of change. According to Prosci, the success of an organizational change initiative depends on how people successfully implement the change. A change is successful only when every impacted employee has reached the five milestones of the ADKAR model, i.e., when the people affected by change are aware of the need and urgency of the change, have the desire to change and have the skills and practical knowledge on how they will work after the change.

The Prosci 3-Phase Process, another component of the Prosci change management methodology, provides a strategic, step-by-step approach to organizational change management. The model encompasses the following phases:

1. Prepare for change. In the first phase the project team designs the change management plans. The activities that should be carried out in this phase are: developing awareness of the need for change; defining change characteristics in terms of size, scope, time and impact; appointing a change management team with clear roles and responsibilities; identifying a sponsor for the change, i.e., a leader across the organization that will push the change and provide resources; identifying groups of individuals impacted by the change; developing a change management strategy.

2. Manage the change. This phase focuses on the development and implementation of various change management plans, i.e., a communication plan, a training plan, a sponsor roadmap, a coaching plan and a resistance management plan.

3. Reinforce the change. In this phase, the change team collects and analyses feedback from people affected by the change, develops mechanisms to measure how well the change is taking hold, controls if employees are actually doing their jobs in the new way, identifies and correct gaps and celebrates success.

\subsection{Salient Activities}

We compared the change management models described above (Table 2); based on the comparison, we identified the salient activities that a successful change initiative should include, namely:

1. Define a strong leadership.

2. Generate awareness of the need for change and develop a sense of urgency towards such a need; to do so, an analysis of the current situation (problems and opportunities that require a change initiative) should be carried out.

3. Define a clear vision and strategy of change: leadership must clearly state the direction in which the organization needs to move and define objectives to achieve it; also, a 
change strategy must be developed to clearly define how the organization intends to achieve the objectives.

4. Communicate change vision and strategy: to prevent resistance to change, the reasons that make the change necessary, the objectives and benefits deriving from the change, and the timing of implementation should be shared with all the members of the organization that are involved in the change initiative.

5. Define a change management team, namely a group of people with well-defined roles and responsibilities, who will drive the change process.

6. Identify short-term goals and test the change in pilot projects: implement early pilot projects to test the change, leverage quick wins to motivate people and adapt knowledge gained in the pilot to a wider rollout of the change.

7. Identify and manage resistance to change. When a change initiative is implemented, inevitably resistance to change arises: people are reluctant to abandon the guaranteed comfort of the status quo, so they see the change as a threat rather than opportunities for improvement and tend to resist to it [21]. For example, a change initiative could make people fear they will be unable to carry out the tasks required by the new way of operating, especially if they are not well trained; it can generate uncertainty and fear of lost work or of an increased workload; also, people may see the change initiative as a threat to interpersonal relationships within the work team. Resistance to change arises especially when people do not understand the reasons and the need for change and the advantages that change will bring to their working conditions.

8. Train people, with the aim of providing them those skills that allow them to carry out tasks in the way suggested by the change initiative.

9. Monitor change, by collecting and analysing feedback from people that are involved in the change initiative.

10. Celebrate the successes achieved in the implementation of change and provide corrective actions to the change management plan when gaps and shortcomings are highlighted.

11. Consolidate the change: realign the organizational structure and people behaviour to the new situation to make change permanent and part of the organization.

Table 2 reports the activities that a change management initiative should include. Although change management models could implicitly include other activities, we considered only the activities that each change management model explicitly envisages.

As reported in Table 2, a change management initiative should start with the definition of a strong leadership that, in turn, should define a clear change vision and strategy and communicate them to all members of the organization. Also, a change management team is required to guide the change process. Once appointed, the team identifies short-term goals and tests the change. Also, it deals with the resistance to change. According to the change management approach, carrying out a change initiative requires managing the effects of a transition on the people involved, encouraging the acceptance of changes and mitigating the problems related to change. Some activities—such as training, monitoring of progress and the celebration of successes-should also be performed to successfully implement the change. Finally, to consolidate it, the organizational structure might need realignment. 
Table 2. Change management activities included in the reviewed models.

\begin{tabular}{|c|c|c|c|c|}
\hline $\begin{array}{c}\text { Change Management } \\
\text { Activities }\end{array}$ & $\begin{array}{c}\text { Kurt Lewin's } \\
\text { Change } \\
\text { Management Model }\end{array}$ & $\begin{array}{l}\text { Kotter's } 8 \text { Step } \\
\text { Change Model }\end{array}$ & $\begin{array}{c}\text { GE's Change } \\
\text { Acceleration Process } \\
\text { (CAP) }\end{array}$ & $\begin{array}{l}\text { Prosci 3-Phase Change } \\
\text { Management Process }\end{array}$ \\
\hline Define a strong leadership & & $\bullet 1$ & $\bullet$ & $\bullet$ \\
\hline $\begin{array}{c}\text { Generate the awareness of } \\
\text { the need for change }\end{array}$ & • & $\bullet$ & & $\bullet$ \\
\hline $\begin{array}{c}\text { Define a clear vision } \\
\text { andstrategy }\end{array}$ & • & • & • & $\bullet$ \\
\hline $\begin{array}{c}\text { Communicate the vision } \\
\text { and strategy }\end{array}$ & • & $\bullet$ & • & $\bullet$ \\
\hline $\begin{array}{l}\text { Define a change } \\
\text { management team }\end{array}$ & & • & & • \\
\hline $\begin{array}{l}\text { Identify short-term goals } \\
\text { and test the change in pilot } \\
\text { projects }\end{array}$ & & • & • & \\
\hline $\begin{array}{l}\text { Identify and manage } \\
\text { resistance to change }\end{array}$ & • & $\bullet$ & • & • \\
\hline Train people & & & & $\bullet$ \\
\hline Monitor change & & & $\bullet$ & $\bullet$ \\
\hline $\begin{array}{l}\text { Celebrate the successes and } \\
\text { implementcorrective } \\
\text { actions }\end{array}$ & & & • & • \\
\hline Consolidate the change & $\bullet$ & $\bullet$ & $\bullet$ & \\
\hline
\end{tabular}

\section{Research Design}

To identify the existing DTMs, we conducted a systematic literature review (SLR), an approach that Tranfield et al. [22,23] suggest as also suitable in the field of management research. Systematic literature review is a replicable, scientific and transparent research approach that seeks to minimize bias and allows the summarizing of all existing information about a phenomenon in a thorough and unbiased manner [22]. Guidance for conducting an SLR, given in Denyer and Tranfield's work [22], encompasses five steps:

1. Question formulation

2. Locating studies

3. Study selection and evaluation

4. Analysis and synthesis

5. Reporting (and use) of the results.

The question that this review intends to address is the following: what are the existing digital transformation models, methods and guidelines to support an organization in the process of digital transformation for the I4.0 transition? Once the review question was defined, an investigation of the citation database Scopus was conducted, at the end of January 2021. A first set of keywords ('digital transformation', 'industry 4.0', 'digitalization', 'smart factory', 'smart manufactur*') was identified to cover the specific domain of investigation; a first research query was obtained by combining these keywords with other terms ('change management', 'organizational change', 'change process', 'change model'); the research query, obtained by applying the appropriate Boolean operators, was used to search into the sections titles/abstracts/keywords of documents included in the Scopus database. A total number of 254 results were retrieved. After a preliminary analysis of the papers, other research terms (roadmap, framework, guide, guideline, approach, model, stage, phase, methodology, process, transition, strategy, journey) were identified; a 
second research string, obtained through the conjunction of these terms with the first set of keywords with the AND operator, was applied to the sections title and keywords of the documents included in the Scopus database and 3135 results were retrieved. All searches conducted were limited to documents written in English. The complete research queries applied to the Scopus database are reported in Table 3.

Table 3. Search queries for data collection.

\begin{tabular}{|c|c|c|}
\hline Search Query & Research String & Records \\
\hline 1 & $\begin{array}{l}\text { TITLE-ABS-KEY ("digital transformation" OR “Industry 4.0" OR digitalization OR "smart } \\
\text { factory" OR "smart manufactur*") AND TITLE-ABS-KEY ("change management" OR } \\
\text { "organizational change" OR "change process" OR "change model") AND (LIMIT-TO } \\
\text { (LANGUAGE, "English")) }\end{array}$ & 254 \\
\hline 2 & 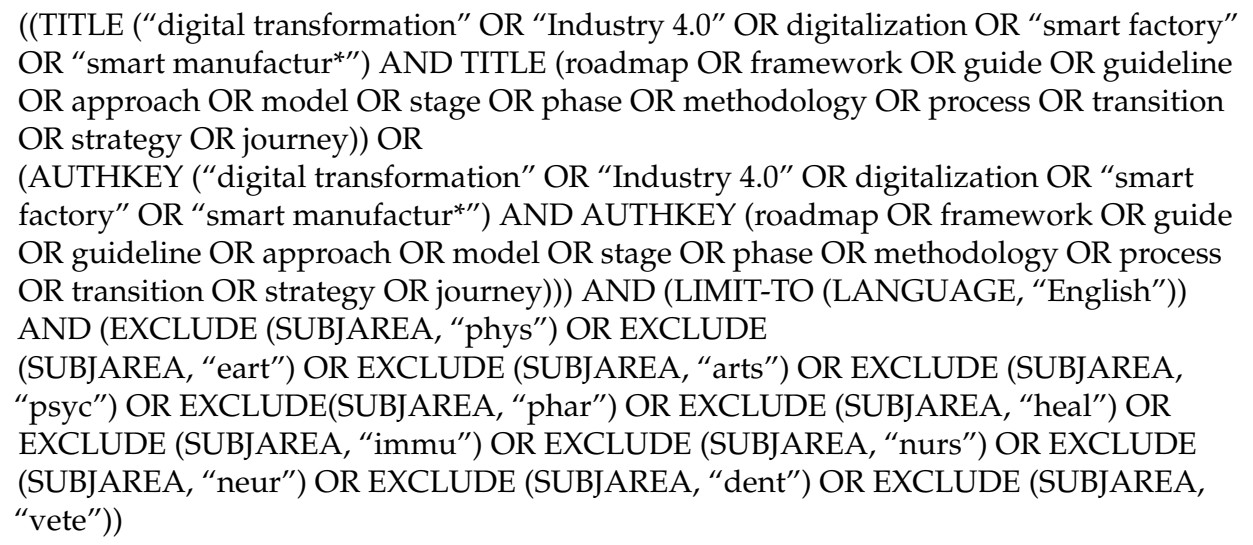 & 3135 \\
\hline
\end{tabular}

The symbol * indicates any combination of characters.

All studies collected were recorded in a single Excel database. A data-cleaning operation was conducted to identify overlaps between results retrieved from the two search queries applied to Scopus: 83 duplicated documents were identified, so reducing the number of documents to 3306. A first screening of the retrieved studies was based on document type to exclude those studies that are categorized as books or book chapters, so only peer-reviewed articles and conference papers were considered in the subsequent phases of the review process. Selection criteria were defined to appraise the relevance of each study and exclude the ones that did not address the review question. Inclusion and exclusion criteria were formulated and applied; the first screening allowed us to exclude those publications that only dealt with the technological aspects of I4.0 (e.g., development of specific applications) and/or in which the topic of I4.0 was adopted to contextualize other themes. A second screening was conducted on abstracts to identify those studies that focused on digital transformation. A total of 183 documents fit these criteria. Ten of them were excluded because their full text was not available. Finally, the full text of the retrieved studies was examined to exclude those that did not present a change model, steps, methodologies or processes to support organizations' digital transformation.

Further research was conducted focusing on grey literature, namely not academic publications retrievable outside of academic databases.

Consulting firms are engaged in supporting companies in the digital transformation and generally provide reports and publication on their websites; thus, the websites of major consulting firms were investigated to detect any contribution, white paper or technical report that provides guidelines for managing the transition toward I4.0. Eight additional contributions were retrieved and included in the literature analysis.

The review process, inclusion and exclusion criteria are shown in Figure 1. 
Detect existing models, methods or guidelines that support organization in the process of digital transformation in the paradigm of Industry 4.0
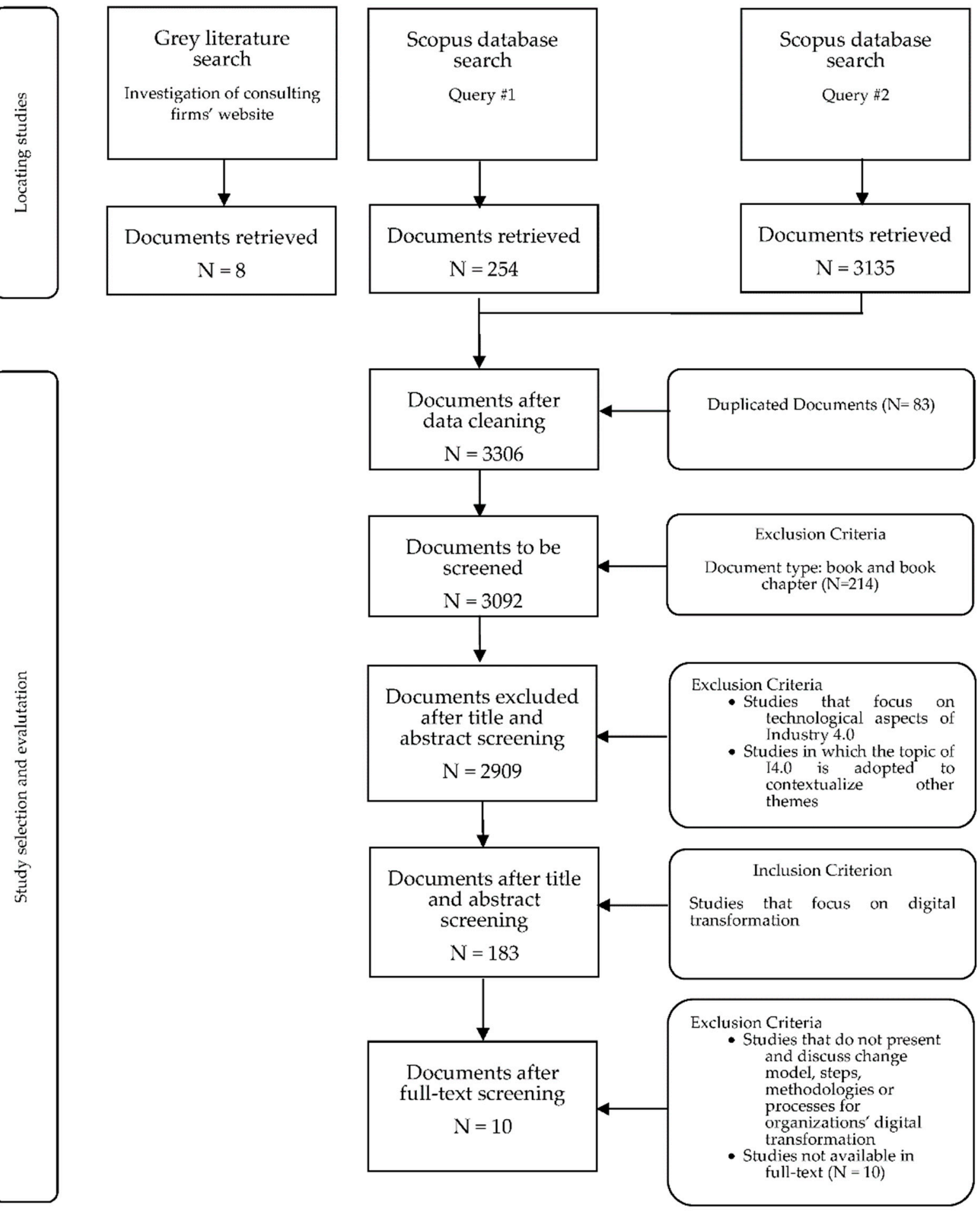

Figure 1. Systematic literature review process.

Literature review results were analysed and discussed. First, an analysis of themes addressed in the academic literature dealing with digital transformation in the paradigm of I4.0 was conducted; then the retrieved DTMs were analysed and compared to pin- 
point their main features, as well as their differences and similarities, based on the following dimensions:

- Phases

- Tools and methods suggested to support the transformation

- Involved stakeholders

- Focus (types of organization for which the model is suitable)

- Theoretical approach (methodology adopted to develop the model)

- Development (activities carried out to develop the model)

- Test (real context, if any, where the model was tested)

Finally, the retrieved DTMs were analysed under the lens of change management. To do so, the activities listed in Table 2 were first contextualized to the case of a specific change initiative, i.e., digital transformation for I4.0 transition. The DTMs were then examined and compared based on the contextualized list of activities.

Based on this, the shortcomings and weaknesses of existing DTMs were identified. Also, suggestions to support organizations that intend to undertake a digital transformation initiative are provided.

\section{Literature Review: Analysis and Results}

In this section the main findings of the systematic literature review are presented. First, a temporal distribution and a thematic analysis of the academic studies dealing with digital transformation in the paradigm of I4.0 is presented; then, all the existing DTMs, both those retrieved in the academic literature and those developed by consulting firms, are described.

\subsection{Literature Analysis}

An analysis of the retrieved studies that dealt with the theme of digital transformation for the I4.0 transition was conducted. As shown in Figure 1, a total of 183 studies that addressed the topic were retrieved and then analysed. Figure 2, which displays the distribution of these studies over time, reveals that scholars' attention has dramatically increased in the last years. A slight majority of these documents (53\%) were indeed published as conference papers, whereas the number of journal articles, which supposedly report the results of more mature studies, is lower.

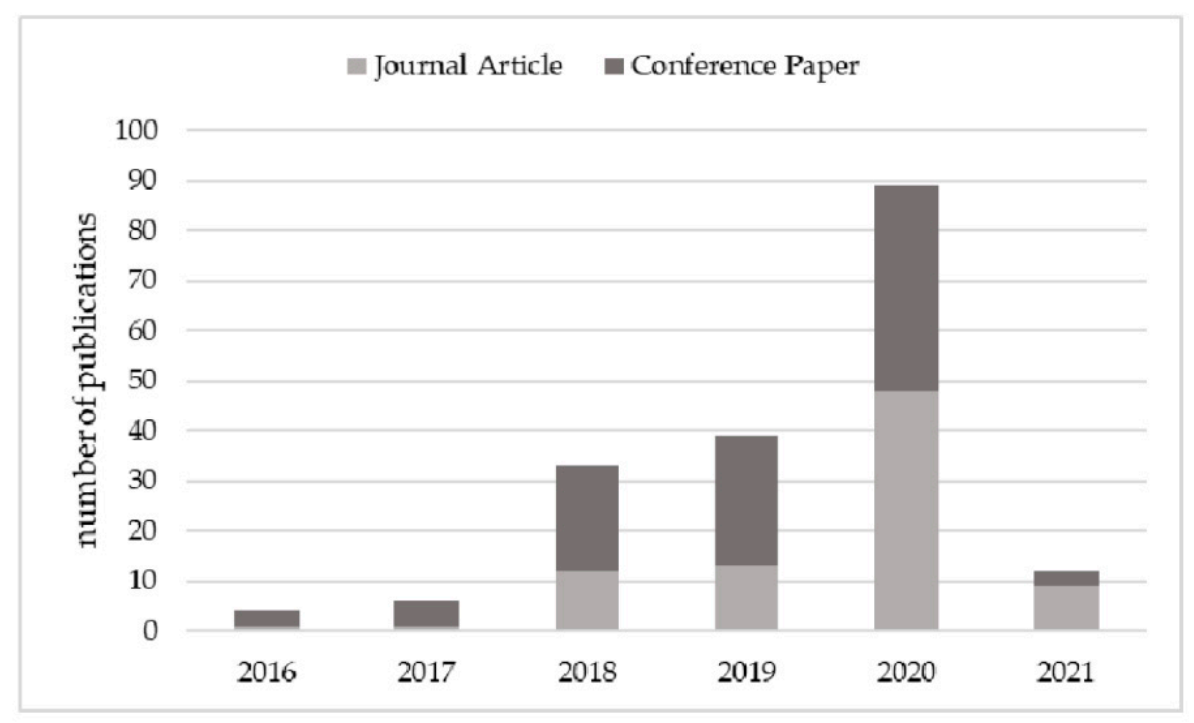

Figure 2. Distribution of publications over the considered period.

The analysis reveals that scholars addressed the issue of digital transformation from different perspectives. A map of the co-occurrence of keywords extracted from the retrieved 
studies was developed by using VOSviewer, a software tool for constructing and visualizing bibliometric networks that also offers text-mining functionality. The map (Figure 3) shows the most frequent keywords that appeared in the literature and highlights the most investigated themes in the domain of digital transformation in the paradigm of I4.0.

$$
\text { life cycle }
$$

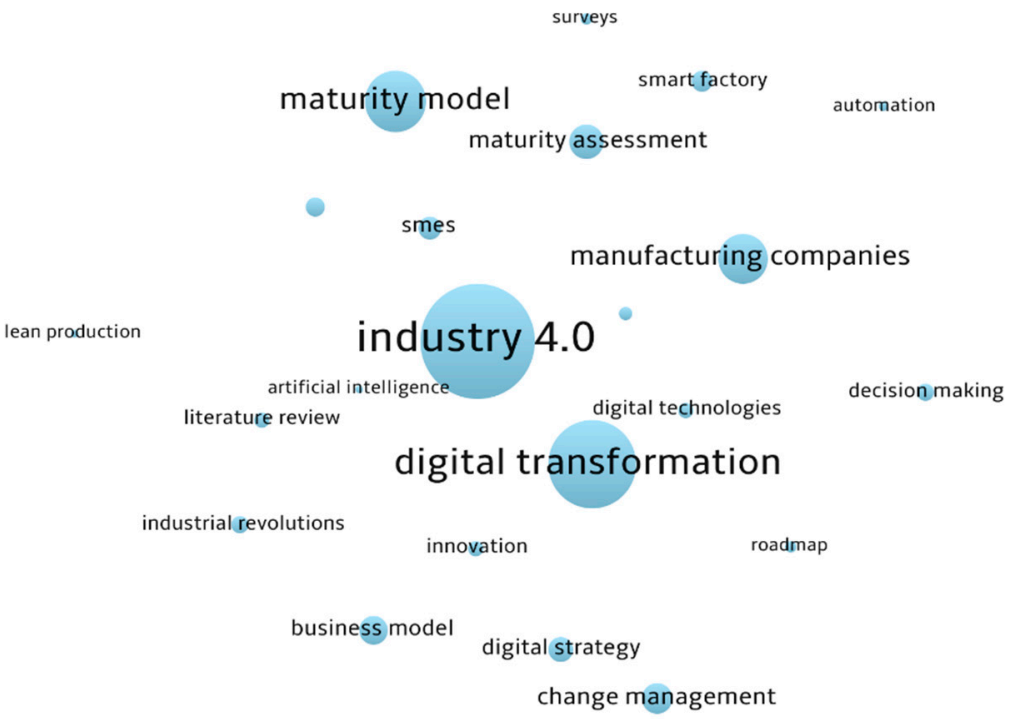

leadership

Figure 3. Keywords map.

Scholars primarily focused on digital maturity assessment; many of them studied the issue of digital readiness of organizations and provided methods and tools to assess states of digital maturity and the readiness for the digital transformation. For example, many studies reported the development of maturity models to assess the digital maturity of manufacturing companies [24-28]; among them, many focused on small and medium enterprises [29,30]; IT companies [31,32] and agriculture companies [33,34] or on specific areas, such as logistics [35,36]. In other studies, models that enable companies to assess their digital capabilities were developed [37,38]. Critical reviews [39-43] of existing I4.0 maturity model were also carried out. Other studies aimed to assist manufacturing companies in the complex issue of I4.0 technology selection: decision-making frameworks [44,45] and project-portfolio management models [46] were developed for this purpose. Factors enabling a successful digital transformation were also investigated: some studies argue that leadership assumes a crucial role in the paradigm shift towards I4.0 and investigated leadership characteristics and skills $[47,48]$.

The analysis of the literature review results also reveals a scarcity of contributions dealing with the overall process of digital transformation and providing complete and structured models to support organizations in the transition towards the I4.0 paradigm [10].

\subsection{Digital Transformation Models}

The systematic review process depicted in Figure 1 allowed the identification of a total of 13 contributions that fit the review question. Such models, eight of which from grey literature and the remaining ten from academic literature, are described below.

Erol et al. [49] suggest a three-stage model, namely (1) envision; (2) enable; (3) enact, for the I4.0 transformation. Such a model is essentially a guiding framework for I4.0 vision and strategy building; it was built upon the concept of co-innovation and strategic road 
mapping, and it is the result of a series of workshops that the authors conducted with the Austrian government, associations, and leading industrial companies. The model was adopted as a guiding framework for raising awareness of the I4.0 vision in the Austrian industrial sector to guide some companies in their first steps towards digitalization. As to the stages, the goal of the first stage (envision) is to develop a tailored I4.0 vision that takes into account peculiarities of the company and its environment; to do so, a participative approach is suggested: the company's stakeholders, primarily the top and middle management, should be involved; to facilitate the building of the vision and raise awareness of the urgency of moving towards digitalization, external experts should also be invited to present relevant best practices. To develop the vision, it is suggested to leverage on co-innovation so meaning that the company must involve all relevant business partners, suppliers and customers. Within the second stage (enable), the company should transform the long-term I4.0 vision into a more concrete business model and develop strategies for a successful implementation; to facilitate the strategy development, road mapping is suggested as a technique for visualization and structuring strategies; finally, in the last stage (enact) strategies are transformed into real projects.

Partially revising the extant literature, Schallmo et al. [50] developed a roadmap for digital transformation for the I4.0 transition that consists of the following five phases:

1. Digital reality. The company's existing business model is sketched along with a valueadded analysis related to stakeholders and a survey of customer requirements. This provides an understanding of the digital reality in different areas of the company

2. Digital ambition. Objectives with regards to digital transformation are defined

3. Digital potential. Best practices and enablers for the digital transformation are established

4. Digital fit. Options for the design of the digital business model are evaluated to determine digital fit with the existing business model

5. Digital implementation. Finalization and implementation of the digital business model; this phase also includes the design of a digital customer experience and digital valuecreation network that describe integration with partners. In addition, resources and capabilities are also identified in this phase.

The authors applied the first phase of their model to a digital transformation project carried on the elevator technology division of a German industry group.

Issa et al. [51] developed a framework to guide manufacturing organizations in the implementation of I4.0. This framework was built on a literature review and then empirically validated through a case study in a German manufacturing company. The proposed steps for the development of a I4.0 roadmap are the follows: (1) task-force set-up; (2) digitalization assessment; (3) focus definition; (4) use-case idea generation; (5) use-case impact estimation and (6) use-case selection. By following these steps, manufacturing organizations are able to create an individual I4.0 roadmap that helps them define a focus for their digitalization activities consistent with their maturity level; the framework envisages the definition of a task force as organizational entity composed by internal stakeholders responsible for operations and external experts of digitalization and I4.0; different tools, like decision matrices, workshops with employees and classification matrices are also suggested to be adopted at each step.

A "Digital Lean Transformation Framework" was proposed by Romero et al. [52] with the aim of providing a practical approach, at the strategic level, to achieve a successful digital transformation aligned with the lean thinking philosophy. The framework was developed based on previous studies on the lean approach and digital transformation and a case study in a manufacturing company was conducted to validate the framework. The "Digital Lean Transformation Framework" involves five management pillars (namely "digital strategic management", "processes re-engineering management", "digital technology management", "change people management", and "digital risk management") which incorporate lean practices and tools. Digital strategic management is the fundamental pillar of the framework; an effective digital strategy should: (a) provide a long-term digital vision as an inspirational goal for the digital-transformation journey; (b) involve a digital 
maturity assessment to break-down the digital vision into targets and identify the internal areas of improvement, including the needed resources and capabilities to implement the digital strategy; (c) evaluate the digital maturity level against the digital vision to articulate goals for each business process to be re-engineered so as to support the digital strategy; (d) select the right technologies and working methods so that the new technology can enable people to do their work according to the new or re-engineered process and create a sustainable competitive advantage; (e) specify how resources will be deployed and the organization will be structured to achieve its digital strategy. Lean tools are suggested to be used in developing a digital strategy. This framework also envisages the creation and development of a digital culture, i.e., a set of values and behaviours, at the personal and organisational levels, driving new digitally enabled ways of thinking, working and interacting with the customer, employees and business units, and with new digital tools. Obeya Room, a lean tool allowing teams to carry out daily meetings with employees to discuss continuous improvements and change enabled by digital technologies, is proposed as a means to support the creation of digital culture.

To lead the digital transformation in the context of I4.0, the so-called agile change management model has been suggested by Le Grand et al. [53]. To develop the model, the authors administered a survey to professionals that had already experienced business changes. The aim was understanding to what extent the greater involvement of people can help in a change project. The proposed model-wherein agile stands for people's involvement in the change project-consists of three phases, the define, experiment, and anchor phases. The first phase (define) should be carried out before the launch of the digital transformation process and it is a diagnostic phase, in which the context of change and the actors involved in the change are defined. Some tools, such us the cartography of change, the cartography of actors and the Change Readiness Questionnaire, are suggested to be adopted in this phase. The experiment phase is at the heart of the agile change model and is organized around two cycles, the workshop cycle and the control cycle, to be performed in parallel and interdependently. The former includes participatory workshops that allow stakeholders to become aware of the need for change so as to involve them in designing the change as well as formative cycles, namely training programs for the people that will be affected by the change. The latter cycle consists in carrying out, at different intervals, measures of change in progress, by surveying individuals who are the beneficiaries of change. Finally, the anchor phase provides a global vision, on a five-year perspective, of the projects carried out, in progress and to come, as well as an analysis of organization's ability to change. A transformation dashboard and business change-assessment grids are tools suggested for this phase. The model has been validated in a retrospective real case (bank digital transformation) and by interviewing experts.

Based on the inputs gathered from experts of digital technologies and business transformation in manufacturing firms, a conceptual model to guide firms to systematically develop action plans for digitalization has been developed by $\mathrm{Ng}$ et al. [54]. Their methodology encompasses five stages, whose inputs and outputs have been clearly defined: (1) the assessment of the current business model; (2) the design of the digital business model; (3) the assessment of the current digital capabilities; (4) the identification of future digital capabilities; (5) the development of the action plan. The first two stages of the model are sequential, whereas the third step can be performed independently. Stage 2's and Stage $4^{\prime}$ s outputs are inputs for the final stage.

Rautenbach et al. [55] made use of a literature review and interviews with experts to derive a digital transformation conceptual model aimed at aiding organizations in the digital transformation process. Their conceptual model consists of two phases: the first includes two sub-phases: phase 1.1 deals with the evaluation of the organization's current value creation process, and phase 1.2, in which the organisation is assessed on in a variety of areas to create a digital profile. Creating a digital profile means conducting an internal and external evaluation of the organization; to do so, three assessments-i.e., a digital capability maturity assessment, a transformation-challenges assessment and a 
market assessment-are carried out. The value creation profile and the digital profile of the organization derived in phase 1 are used as inputs for phase 2, whose results are integrated to guide the organization in creating value leveraging the digital dimension.

Pessl et al. [56] suggest a model to make companies analyse their individual maturity levels, identify their own targets and develop a specific action plan to implement the I4.0 strategy. The model was developed in collaboration with a renowned Austrian industrial company. First, to generate awareness on the importance of I4.0 within the company, a kick-off workshop is held; a collection of I4.0 use cases is presented to demonstrate the benefits of the use of new technologies. In this phase, a SWOT analysis can be also conducted to pinpoint opportunities and threats of I4.0 (external view) as well as strengths and weaknesses (internal view). The second step of the model deals with ascertaining the company's status and existing I4.0 competences: this assessment is conducted for each function (purchasing, production, intralogistics, sales and human). In the third step, a target state for each function is defined. Based on the defined targets, in step four concrete measures to determine the difference between the current and the target maturity level are derived, documented and evaluated. In step five, the defined targets and measures are selected and transferred to a balanced scorecard; finally, concrete I4.0 implementation projects are defined and connected with budgets. The model advises starting with pilot projects of digitalization and to incorporate the gained experiences into subsequent digitalization projects.

Leone et al. [57] suggest a methodological framework to assist SMEs that do not have management processes and/or resources capable of systematically identifying innovation gaps and transforming them into I4.0 integration projects. The methodology envisages three stages: (1) I4.0 maturity assessment, (2) process as-is analysis and (3) I4.0 roadmap design. In the first stage, questionnaires or interviews to representatives of the company departments are administered to assess the maturity of the company with respect to five main areas influencing the I4.0 transition, i.e., strategy, processes, technologies, products and services and people; in this stage, a strategic vision is defined, as well. In the second stage, a formalization of the as-is situation is carried out with the support of managers and operators; to this end, for each process considered, mapping the fundamental elements (activities, input and output, digital data, and technological infrastructure) is carried out. In the third stage, a I4.0 roadmap that identifies and prioritize specific I4.0 projects is developed. In this last stage, workshops with the main internal stakeholders are organized to discuss problems associated with each activity (pain) and related desired improvements (gain); both pains and gains are used as starting points for the identification of a list of innovation projects. At this point, a decision support tool based on the analytical hierarchy process (AHP) is applied to guide decision makers in prioritizing the most relevant projects. The prioritized projects are identified, and a roadmap is developed and integrated with the strategic vision. The activities envisaged in this third stage should be iterative, with the aim of integrating a continuous improvement approach into the process, so as to extend the digitalization to all the company's processes. This methodology was applied in a pharmaceutical company as a method to create a preliminary analysis of needs in term of digitalization.

Butt [58] derives an integrated business-process management framework (IBPM) based on narrative literature review. The framework, rooted in the tradition of BPM, is proposed as a method that can be used to support manufacturing organizations' journey towards I4.0. The framework includes the following phases:

1. Process Identification. An IBPM team is defined, comprising senior management members, process owners, process analysts and system engineers from each department of the organization. In addition, the expectations of internal (employees) and external stakeholders (customers) are detected by means of tools such as organizational charts, SWOT analysis, stakeholder maps, context diagrams and business-case diagrams. 
2. Process Discovery. Business processes to be improved and reengineered are identified; process maps (e.g., in BPMN language) and value-stream maps help the IBPM team to understand the "as-is situation" and assess the workflows and their shortcomings.

3. Process Analysis. As-is processes are analysed, and performance indicators defined.

4. Process Redesign. The goal of this phase is to identify changes to address the issues identified in the previous stages. Changes can be implemented by either redesigning and improving the existing processes or designing new processes. Simulation tools (e.g., Petri Net, Monte Carlo simulations) are extremely useful in this phase. The output of this phase is a list of to-be alternatives, which should be then discussed and prioritized to identify the optimal option; a Pugh matrix is suggested as a tool for ranking the multidimensional options and identifying the optimal one.

5. Streamlining Business Processes. Once the to-be processes are defined, it is vital to streamline other business processes; indeed, as an effect of to-be processes, there could be changes in the interdependencies between business processes.

6. Risk Management. The IBPM team analyses and identifies risks that may occur when digital technologies are introduced in the processes. A risk assessment can be conducted through brainstorming sessions and by developing a risk register, which quantifies the probabilities and impacts of each.

7. Skill-Gap Analysis. The IBPM team conducts a skill-gap analysis to assess the workforce with respect to existing and required skills.

8. Change Management. The IBPM team designs a change management strategy to gradually change the mindset of the workforce and senior management and to instil the idea that there is no end to change. To do so, the team can choose a change management model (e.g., ADKAR model, Lewin's change management model, Kotter's change management model).

9. Cost-Benefit Analysis. The IBPM team conducts a cost-benefit analysis based on the to-be processes developed in Phase 4 through simulation models. The team needs to consider every single benefit that can result from employing I4.0-enabling technologies, convert these benefits into monetary values and judge them against the associated costs. A structured method (Phillips' ROI methodology) is suggested to support this activity.

10. Process Validation and Implementation. Before moving to full-scale implementation, the to-be processes should be validated; thus, the team should plan and conduct a pilot run; it can help to minimize failure risks, identifying additional improvement; after piloting, a full-scale implementation is realized.

11. Process Monitoring and Control. Once the to-be business process is running, the ongoing activity of process monitoring and control should be carried out to continuously improve business processes. A lean six-sigma approach is suggested to manage this phase.

As to the analysis of grey literature, eight main contributions were retrieved: the selected documents were published in between 2014 and 2021 by the major consulting firms globally engaged in digital transformation projects.

Capgemini Consulting [59], based on its experience in digital transformation projects, recommends manufacturing companies to embark on a six-step journey towards I4.0:

1. Conduct a digital maturity assessment. The starting point for the journey towards I4.0 is a deep understanding of the status of digitization in the organization.

2. Identify opportunities and threats in I4.0 environment. Once organizations have a clear perspective on their digital maturity, they need to explore the corporate environment for opportunities and threats triggered by the fourth industrial revolution; an exploration of altering customers' demand, opportunities provided by digitalization, and how competitive dynamics are evolving should be the focus of this step.

3. Define I4.0 vision and strategy. Based on previous analyses, companies must develop a clear vision for their own place in the next industrial era. The vision should provide a comprehensive view on how the company aims to do business in the future. The 
vision defines short- and long-term objectives that the company intends to achieve through digital transformation and provides the basis for deriving a strategy to become a digitalized manufacturing company.

4. Prioritize the transformation domains. Depending on the required level of integration with existing core business processes and systems, some domains will be easier to transform than others. So, organization should prioritize the transformation domains and identify the digitalization initiative to undertake; a prioritization matrix also helps in identifying quick wins on the path towards I4.0.

5. Derive the roadmap towards I4.0. Based on the digitization initiatives identified in the previous phase and the priority given to each of them, a roadmap towards I4.0 is generated. The roadmap contains details of transformation phases and helps to make tangible the journey towards digital transformation.

6. Implement and sustain the change. Concrete actions must be adopted for the implementation of the digital roadmap to improve the level of digitization of the organization and integrate digitalization into the culture of the organization.

In all the steps, the leadership has an essential role in driving the digital transformation. Accenture [60] provides customer-focused actions (i.e., actions that keep the customer experience at the centre) to undertake a digital transformation journey:

1. Broaden the definition of digital. Companies must infuse digital experiences into every aspect of the business, creating an enterprise-wide digital ecosystem that includes people, processes, and technologies.

2. Discover how in love customers really are. Companies must adopt benchmarking practices based on customer-focused metrics that allow understanding how customers feel about the company, how well customers are satisfied and how well customer experience is managed.

3. Build momentum from the top. Digital transformation must start at the top of the organization. Additionally, all top management levels must be committed and work in a highly collaborative manner toward shared goals.

4. Teach the power of digital. As in many organizations, digital expertise is held by a select few people, it is imperative that digital knowledge becomes embedded throughout the organization; to this aim, digital training programs are suggested.

5. Encourage digital accountability. Companies can set digital key performance indicators for personnel in all areas of the organization and reward high performers with incentives.

6. Commit to never being satisfied. Companies should adopt an entrepreneurial spirit to identify new opportunities to digitally innovate the business.

7. Invest beyond the here-and-now. Digital gains are not necessarily immediate. Companies must pursue digital transformation as part of a lasting vision for change, making long-term investments rather than focusing only on point solutions that promise an immediate payoff.

Kearney provides Integral 2.0 [61], an approach designed to address the key challenges faced during a digital transformation initiative. The approach comprises six building blocks to drive transformation across an organization. It is anchored in two, clear imperatives: being digital and doing digital:

1. Being digital:

a. Success definition: vision and digital targets are determined to set up the direction of the digitalization program

b. Digital domain structure: high-potential business domains to digitalize are identified

c. Digital upskilling: improve the digital competences of the workforce by adopting experiential learning

2. Doing digital:

a. Innovation engine: implementation of a portfolio of digital innovations for each domain, crowdsourced from the whole organization 
b. Execution engine: implementation of digital factories to test digital solutions and rapidly execute and scale them

c. Scaling engine: set-up of a control tower, a governance body that oversees the full transformation program, proactively removes obstacles and helps scale innovations across the organization.

Based on hundreds of transformation projects with leading industrial companies, PricewaterhouseCoopers (PwC) defined the "Blueprint for Digital Success" [62], which includes six practical steps to lead companies' digital transformations:

1. Map out I4.0 strategy. The I4.0 strategy will shape every step to be taken in the path towards becoming a fully digital enterprise; so, it is important to take enough time to clearly define it. First, the company must evaluate its digital maturity level to understand strengths and weaknesses to work on; $\mathrm{PwC}$ provide a tool $\mathrm{PwC}$ maturity model) that helps to speed up this process. In this phase, clear and strong leadership from top management is critical to convince all stakeholders of the need for change.

2. Create initial pilot projects. Identifying pilot projects and implementing them is a good way to overcome the initial challenges of digital transformation; in this phase crossfunctional teams must be set up; pilot teams completely dedicated to pilot projects will be able to pragmatically design changes to compensate for standards or infrastructure that don't yet exist. To do so, companies should consider collaboration with digital leaders outside the organization (e.g., start-ups and universities) to accelerate digital innovation. Evidence from early successes should be useful for a wider rollout of digital transformation.

3. Define the capabilities needed. Building on the lessons learned in pilot projects, the company has to map in detail the capabilities needed to enable new digital business models; the success of I4.0 initiatives depends on digital skills and knowledge that the company is able to recruit or train. So, the company should introduce new figures, like data scientists, user-interface designers or digital innovation managers, by recruiting new employees or training existing ones to put digitization into place.

4. Become a virtuoso in data analytics. Defining and developing an effective data analytics strategy that allows identifying and gathering the right data, deploying it for the right purposes and effectively analysing it is critical to I4.0 decision making.

5. Transform into a digital enterprise. Creating a digital culture and a truly digital environment is possible only if organization's leadership places digital transformation among the top priorities of its agenda.

6. Actively plan an ecosystem approach. An effective improvement of the company's performance takes place when the organization integrates digital technologies along the entire value chain so as to obtain data and information on consumers' needs, but, also, to exchange data with partners and suppliers.

The Boston Consulting Group also provides guidelines to help manufacturers develop their digital transformation initiatives. According to their guidelines, the main steps are [63]:

1. Understand the value of making the change. Management should gain an in-depth understanding of how to leverage on I4.0 to improve operations and create value. To obtain a variety of perspectives on I4.0 and evaluate potential from different angles, it is essential to reach out to a broad set of experts.

2. Assess the current state of systems and operations. To understand the starting point and business needs, the company should assess its current systems and identify pain points in its operations; the BCG I4.0 health-check tool helps in highlighting areas for improvement and suggests specific use-cases useful in managing the digital transition.

3. Define a roadmap and vision. The company can use the assessment results to create a strategic roadmap for I4.0. The roadmap should set out the transformation's priorities with respect to the technologies and use-cases to implement. Initiatives to implement use-cases should be sequenced so that the company can pursue "no regrets" moves 
that unlock value rapidly, thereby generating momentum and funds to support the overall journey. The resource requirements for each stage should also be identified. It is critical to avoid independent initiatives scattered throughout the company, without a clear vision and coordination from the top.

4. Improve existing processes. Existing processes typically offer the best opportunities for capturing rapid value through the deployment of I4.0 technologies. The deployment should occur in three phases:

a. Conduct proof-of-concept pilots. A company should use proof-of-concept pilots to test a set of technologies in specific processes. By analysing the pilots' results and benefits, a manufacturer can validate the business case for full-scale implementation and identify the requirements for managing the new technologies.

b. Create a reference factory. Before rolling out a set of technologies in all facilities, a company should evaluate the potential overall impact by implementing the set across the end-to-end processes of one factory. Alternatively, a company may create reference processes, implementing a set of technologies in specific processes.

c. Roll out the new technologies. Applying the knowledge gained from the pilots and a reference factory or reference processes, a company should roll out the set of technologies to all facilities, integrating it with existing systems and processes.

5. Expand capabilities along the value chain. Beyond improving internal processes, a company should explore opportunities to use I4.0 to better integrate its operations with those of customers and suppliers. Integrating operations along the value chain is a higher level of maturity and assures significant benefits in terms of better planning and production management, supply-chain transparency and inventory optimization.

Based on digital transformation efforts and experiences already conducted in the insurance industry, McKinsey developed ten guiding principles of digital transformation dedicated to insurance companies [64]; these principles are embedded into a three-step model:

1. Defining value. To set a digital transformation on the right course a company must place it at the core of its agenda and must reflect on the magnitude of that undertaking; top management must grasp the fundamental importance of its commitment, must be willing to make significant investments and to set clear and ambitious targets.

a. Secure senior management commitment. A digital transformation initiative must have a strong commitment from the senior management, who must define a digital vision; the vision and the objective of the digital transformation initiative must be communicated. Also, it must be clarified that digital transformation is an unquestionable priority

b. Set clear and ambitious targets. Digital investments must be linked to clear and ambitious targets. This is a signal of the magnitude of what digital technology can deliver. Without targets, people could find the change difficult to accept; setting clear targets at the outset prevents back-sliding when the digital initiative is going on and it imposes discipline on the process of deciding which initiatives to pursue for maximum impact. Targets are needed for each source of value creation-cost savings, revenues, improved performance of agents and the satisfaction of employees and customers-and for new ways of working and the new capabilities required

c. Secure investments. Digital transformation requires significant investment. Companies will need to allocate investment both to improve the current business and to build new businesses as the insurance model evolves.

2. Launch and acceleration. When a digital transformation initiative is launched, to ensure that early efforts build momentum, companies should carefully consider the projects to start with. Also, the necessary resources should be provided to those projects. Prerequisites include a launch team, considerations of organizational structure and 
the nurturing of a digital culture. Otherwise, the initiatives fail to take off and the old ways of doing business return:

a. Start with lighthouse projects. To win early support, companies should start with projects that offer the potential for significant rewards with manageable risk; to this end, digitalization pilot projects are suggested (e.g., customer services and claims processes).

b. Appoint a launch team. Companies should appoint a launch team, often led by a chief digital officer (CDO) to coordinate the transformation, decide the sequence of the transformation, ensure the appropriate technology and skills and monitor progress against targets. The launch team should include designers to contemplate customers' unmet needs and inform the creation of experiences, products and services; data scientists; scrum masters to facilitate agile development and developers who can work in the modern IT environment. McKinsey suggests a way to build an effective launch team, namely, to start by hiring a renowned expert to serve as an anchor hire that will help attract others.

c. Organize to promote new, agile ways of working. To undertake a successful digital transformation, a new organizational structure should be implemented; it is suggested to create a digital unit separated from the rest of the organization. This digital unit may promote new ways of working that are essential for digital success and attract and retain specialists, while offering them freedom from incumbents' organizational constraints. However, the digital unit must be then reintegrated at some stage, and that becomes more difficult as time passes.

d. Nurture a digital culture. Insurance companies should start to create a digital culture; this means that the new ways of working and thinking-fast, collaborative, empowered-which will be the default mode of a digitally transformed company needs to take hold across the organization.

3. Scaling up. After an initial phase of digital transformation (generally 18 months), companies should have a certain number of digital projects running and be starting to capture value; this is the time to supercharge the transformation. Key activities to perform in this phase are:

a. Sequence initiatives for quick returns. Identify a good sequence of initiatives to scale fast: initiatives that are strategically important, are paid back quickly and which reduce complexity are those to prioritize.

b. Build capabilities. Close attention will need to be paid to building more capabilities; the right digital capabilities should be recruited and hired; a huge internal training effort will be needed as well. It will be important to help all employees rethink the way they work

c. Adopt a new operating model. To reap the full rewards of a transformation, eventually an entirely new operating model will be required; whatever organizational structure a company chooses initially, it must be redesigned for the transformation to succeed.

Based on the experience generated by the collaborations with several high-tech and industrial companies supported in their digital transformation journeys, Deloitte [65] proposed a digital industrial transformation framework based on four core aspects: strategy, business model, capabilities and operating model. Articulating the digital transformation strategy should be the first step carried out. It clarifies the transformational programs, as well as the company's decisions on how to adapt its business model, capabilities and operating model. The digital transformation strategy—which Deloitte also calls the digital north star-is a compelling statement that should clearly express the long-term vision, short- and medium-term objectives and also the meaning of digital transformation for customers. Formulated and communicated to stakeholders, the digital strategy ensures that all stakeholders clearly understand the aspiration, intended outcomes and rationale for the transformation; it also makes employees-which could have difficultly internalizing the 
motivations for digital change-more motivated and engaged in the digital transformation journey. To launch and manage the transformation, the framework also suggests defining a transformation team - which could be a separate, cross-functional team, aligned to a specific line of business or embedded within existing teams-to drive the change and achieve the desired outcomes. After articulating the transformation north star, defining the business model is the next step. The market and the segments in which the company wants to play must be chosen, products or services to be offer and the ways those offerings might be monetized must also be defined. To successful operate a digital transformation, company must align the operating model with the digital strategy. This means that the top management must revise the company's operating model (i.e., how value is created, and by whom, within the company). So, in moving forward with a digital transformation, the company must identify the set of capabilities required to meet the enterprise's strategic digital ambitions. Company must articulate a map of capabilities to determine skills requirements and talent to acquire, but also to set performance metrics and to identify partnership opportunities. Once leaders have established the capability map, the next step is sourcing capabilities; companies typically have four sources for them: developing, transforming or maturing capabilities internally; acquiring them through targeted hires; partnering to access capabilities; or outsourcing capabilities so as to have them delivered as a service.

Recently, McKinsey proposed a six-building-block model to help industrial companies implement a successful end-to-end transformation that goes far beyond simple technology upgrades [66]. The six building blocks of the digital transformation are:

1. Creating a business-led technology road map. Company leaders must first develop a digital vision of the organization; also, they must define a clear digital strategy and a new value proposition for their company. Defining a digital strategy means considering new engagement, transaction and fulfilment rules (e.g., which customers will be engaged in direct online transactions, and which will be engaged through distributors); also, a solid digital strategy should consider pricing issues. When developing a digital roadmap, the industrial companies should consider the strategic implications for the incumbent business, including disruptions to any offline distribution channels as digital sales grow.

2. Developing and up-skilling talent. Before implementing their road maps, companies must identify the key roles necessary for a digital organization. They should first evaluate their talent needs and identify gaps by looking at both immediate and longterm needs. They should then determine if they can fill any spaces by upskilling employees or recruiting externally; in the first case, digital-learning programs to increase knowledge and capabilities across the organization should be provided.

3. Adopting an agile delivery methodology. Company must also create an environment that makes it possible to test new approaches or technologies quickly and then iteratively make improvements based on customer feedback; digital campaigns to rapidly test the digital strategy and make revisions based on insights gleaned from the field are suggested.

4. Shifting to a modern technology environment. New digital technologies are the foundation of any digital transformation. Companies must create a new technological environment that covers areas including commerce backbone services, front ends and integration architecture.

5. Focus on data-management enrichment. Companies must improve data management because, without robust, data-driven insights, they may have problems in the identification of priority actions and in finding synergies across business lines.

6. Driving the adoption and scaling of digital initiatives. While digital pilots may produce solid returns, companies must implement programs across the entire organization to drive real impact. Scale-up will require new enterprise-wide business processes with focus on changes that must occur in three categories of business processes, 
namely, product, service and order fulfilment, commercial strategy and execution and customer services and transactions.

\section{Digital Transformation Models and Change Management}

In this Section we first analyse and compare the retrieved DTMs based on the dimensions of analysis discussed in Section 3, namely phases, tools and methods, involved stakeholders, focus, theoretical approach, development and testing. Then we investigate the DMTs under the lens of change management literature.

\subsection{Comparison of DTMs}

The digital transformation models, both retrieved from the academic literature and provided by consulting firms, are schematically described in Table 4. Most DTMs are focused on manufacturing companies. Only one model [64] is focused on other industries, in particular in insurance.

Consulting firms' DTMs are developed based on the experiences of real digital transformation projects. Most models (6/10) proposed in the academic literature were developed by revising/based on extant studies or by distilling experience from workshops or surveys conducted with experts of digital technologies and business transformation. However, most of them were tested in real contexts, namely applied to manage companies' digital transformation initiatives.

Only three DTMs—i.e., Erol et al. [49], Romero et al. [52] and Butt [58] — explicitly mention the theoretical approach used to develop them, which are, respectively, co-innovation and strategic road mapping, the lean thinking philosophy and business process management.

Many DTMs retrieved from the academic literature recommend the involvement of stakeholders in the different phases of digital transformation process; in particular, it is suggested to involve employees and management, as internal stakeholders, and external experts of digitalization, customers and business partners, as external ones. However, most consulting firms' models do not explicitly discuss such an aspect. Only the Accenture's DTM explicitly refers to customers as the main stakeholders around which to build the digital transformation.

The analysis also shows that many DTMs address digital transformation only at the strategic level (more attention is devoted to the definition of I4.0 strategy and roadmap), whereas the implementation and consolidation steps are often neglected. However, the BCG's and PwC's DTMs suggest expanding digital capabilities along the value chain in the last phase of the model, so as to obtain a higher level of digital maturity.

Several tools and methods to support the proposed phases are reported in most DTMs. For instance, tools like surveys, questionnaires and interviews are suggested in the initial phases of DTMs to appraise the company's digital maturity; consulting firms' DTMs, provided by PwC and BCG, also suggest valid tools to conduct company's digital maturity assessment; process flow charts, business model canvases and value stream maps are used in several DTMs to describe the company's current situation; workshops and brainstorming sessions support the definition phase of digitalization goals; classification matrices, the AHP method and decision matrices are suggested in some DTMs to identify and prioritize digitalization projects. 
Table 4. Overview of DTMs.

\begin{tabular}{|c|c|c|c|c|c|c|c|}
\hline Authors & Description/Phases & Tools and Methods & Involved Stakeholders & Focus & Theoretical Approach & Development & Test \\
\hline \multirow[t]{3}{*}{ Erol et al. (2016) [49] } & $\begin{array}{l}\text { understanding I4.0 } \\
\text { basics } \\
\text { definition of company } \\
\text { specific I4.0 vision }\end{array}$ & & $\begin{array}{c}\text { company stakeholders } \\
\text { (top management, } \\
\text { middle management, } \\
\text { business partners, } \\
\text { suppliers and } \\
\text { customers), external } \\
\text { experts }\end{array}$ & \multirow[t]{3}{*}{$\begin{array}{c}\text { manufacturing } \\
\text { companies }\end{array}$} & \multirow[t]{3}{*}{$\begin{array}{l}\text { co-innovation and } \\
\text { strategic road mapping }\end{array}$} & \multirow{3}{*}{$\begin{array}{l}\text { workshops conducted } \\
\text { with Austrian } \\
\text { government, } \\
\text { associations and } \\
\text { leading industrial } \\
\text { companies }\end{array}$} & \multirow[t]{3}{*}{$\begin{array}{l}\text { several Austrian } \\
\text { industrial companies }\end{array}$} \\
\hline & $\begin{array}{c}\text { roadmapping of I4.0 } \\
\text { strategies Identification } \\
\text { of internal and external } \\
\text { success factor }\end{array}$ & strategic roadmap & & & & & \\
\hline & $\begin{array}{c}\text { preparation of } \\
\text { transformation } \\
\text { proposal of I4.0 projects }\end{array}$ & & & & & & \\
\hline \multirow{4}{*}{$\begin{array}{l}\text { Schallmo et al. (2017) } \\
\text { [50] }\end{array}$} & digital reality & surveys & $\begin{array}{l}\text { internal stakeholders, } \\
\text { customers, business } \\
\text { partners }\end{array}$ & \multirow{4}{*}{$\begin{array}{c}\text { manufacturing } \\
\text { companies }\end{array}$} & \multirow{4}{*}{-} & \multirow{4}{*}{ literature review } & \multirow{4}{*}{$\begin{array}{l}\text { technology division of } \\
\text { a German industry } \\
\text { group }\end{array}$} \\
\hline & digital ambition & & & & & & \\
\hline & digital potential & & & & & & \\
\hline & digital implementation & & & & & & \\
\hline \multirow{4}{*}{ Issa et al. [51] } & focus definition & decision matrix & & \multirow{4}{*}{$\begin{array}{c}\text { manufacturing } \\
\text { companies }\end{array}$} & \multirow{4}{*}{-} & \multirow{4}{*}{ literature review } & \multirow{4}{*}{$\begin{array}{c}\text { German manufacturing } \\
\text { company }\end{array}$} \\
\hline & use-case idea generation & $\begin{array}{c}\text { workshops and } \\
\text { brainstorming sessions }\end{array}$ & $\begin{array}{l}\text { staff-level and } \\
\text { employees }\end{array}$ & & & & \\
\hline & use-case impact estimation & classification matrix & & & & & \\
\hline & use-case selection & & & & & & \\
\hline
\end{tabular}


Table 4. Cont.

\begin{tabular}{|c|c|c|c|c|c|c|c|c|}
\hline Authors & Descri & Phases & Tools and Methods & Involved Stakeholders & Focus & $\begin{array}{l}\text { Theoretical } \\
\text { Approach }\end{array}$ & Development & Test \\
\hline \multirow[t]{5}{*}{$\begin{array}{c}\text { Romero et al. (2019) } \\
{[52]}\end{array}$} & \multicolumn{2}{|c|}{ digital strategic management } & lean tool (Hoshin Kanri) & $\begin{array}{l}\text { customers, employees, } \\
\text { expert collaborators } \\
\text { (i.e., external } \\
\text { consultants, } \\
\text { universities) and } \\
\text { technology partners }\end{array}$ & \multirow[t]{5}{*}{$\begin{array}{c}\text { manufacturing } \\
\text { companies }\end{array}$} & \multirow[t]{5}{*}{$\begin{array}{c}\text { lean thinking } \\
\text { philosophy }\end{array}$} & \multirow[t]{5}{*}{ literature review } & \multirow[t]{5}{*}{$\begin{array}{l}\text { building materials } \\
\text { company }\end{array}$} \\
\hline & \multicolumn{2}{|c|}{ processes re-engineering management } & $\begin{array}{c}\text { design } \\
\text { thinking } \\
\text { sessions } \\
\text { lean tool (value-stream mapping) }\end{array}$ & & & & & \\
\hline & \multicolumn{2}{|c|}{ digital technology management } & lean start-up methodology & & & & & \\
\hline & \multicolumn{2}{|c|}{ change people management } & lean tool (Obeya Room) & & & & & \\
\hline & \multicolumn{2}{|c|}{ digital risk management } & $\begin{array}{c}\text { lean tools (five whys and Ishikawa } \\
\text { fishbone diagram, A3 sheet management } \\
\text { for risk evaluation, PDCA cycle for risk } \\
\text { treatment) }\end{array}$ & & & & & \\
\hline \multirow[t]{4}{*}{$\begin{array}{l}\text { Le Grand and } \\
\text { Deneckere (2019) [53] }\end{array}$} & \multicolumn{2}{|c|}{ define phase } & $\begin{array}{l}\text { cartography of change (questionnaire tool } \\
\text { that allows to identify areas of change) } \\
\text { cartography of actors (characterization of } \\
\text { actors involved in the change by type, } \\
\text { number, location, role, importance degree } \\
\text { and risk level) } \\
\text { change readiness (questionnaire tools that } \\
\text { allows to evaluate people's acceptance or } \\
\text { refusal of change) }\end{array}$ & \multirow[t]{4}{*}{$\begin{array}{l}\text { all stakeholders } \\
\text { affected by the digital } \\
\text { change }\end{array}$} & \multirow[t]{4}{*}{-} & \multirow[t]{4}{*}{$\begin{array}{l}\text { agile change } \\
\text { management }\end{array}$} & \multirow[t]{4}{*}{$\begin{array}{l}\text { survey } \\
\text { administrated to } \\
\text { professionals with } \\
\text { experience in } \\
\text { business changes }\end{array}$} & \multirow[t]{4}{*}{$\begin{array}{l}\text { bank digital } \\
\text { transformation } \\
\text { project }\end{array}$} \\
\hline & \multirow[t]{2}{*}{ experiment phase } & $\begin{array}{l}\text { workshop cycle } \\
\text { (participatory and } \\
\text { formative) }\end{array}$ & $\begin{array}{l}\text { workshops and brainstorming session } \\
\text { training programs (individual or } \\
\text { collective) }\end{array}$ & & & & & \\
\hline & & control cycle & $\begin{array}{l}\text { surveys about the progress of change } \\
\text { (through discussions on a company's } \\
\text { social network or through } \\
\text { inter-views/questionnaires) }\end{array}$ & & & & & \\
\hline & anc & lase & $\begin{array}{l}\text { transformation dashboardbusiness change } \\
\text { assessment grid (a matrix for assess the } \\
\text { organization's ability to change) }\end{array}$ & & & & & \\
\hline \multirow{5}{*}{ Ng et al., (2019) [54] } & \multicolumn{2}{|c|}{ assessment of current business model } & $\begin{array}{l}\text { business model } \\
\text { canvas }\end{array}$ & \multirow{5}{*}{-} & \multirow{5}{*}{$\begin{array}{l}\text { manufacturing } \\
\text { companies }\end{array}$} & \multirow{5}{*}{-} & \multirow{5}{*}{$\begin{array}{l}\text { workshop with } \\
\text { experts of digital } \\
\text { technologies and } \\
\text { business } \\
\text { transformation in } \\
\text { manufacturing } \\
\text { firms }\end{array}$} & \multirow{5}{*}{-} \\
\hline & design of dig & siness model & digital value-drivers matrix & & & & & \\
\hline & assessment of cur & igital capabilities & digital capabilities maturity models & & & & & \\
\hline & identification of $\mathrm{f}$ & gigital capabilities & - & & & & & \\
\hline & \multicolumn{3}{|c|}{ development of action plan } & & & & & \\
\hline
\end{tabular}


Table 4. Cont.

\begin{tabular}{|c|c|c|c|c|c|c|c|c|}
\hline Authors & Descrip & /Phases & Tools and Methods & Involved Stakeholders & Focus & $\begin{array}{l}\text { Theoretical } \\
\text { Approach }\end{array}$ & Development & Test \\
\hline \multirow{5}{*}{$\begin{array}{l}\text { Rautenbach et al. (2019) } \\
{[55]}\end{array}$} & $\begin{array}{l}\text { value creation } \\
\text { assessment }\end{array}$ & & - & \multirow{5}{*}{-} & \multirow{5}{*}{-} & \multirow{5}{*}{-} & \multirow{5}{*}{$\begin{array}{c}\text { literature review } \\
\text { and experts' } \\
\text { interviews }\end{array}$} & \multirow{5}{*}{-} \\
\hline & \multirow{3}{*}{$\begin{array}{l}\text { digital organization } \\
\text { profile }\end{array}$} & $\begin{array}{c}\text { digital capability } \\
\text { maturity assessment }\end{array}$ & - & & & & & \\
\hline & & $\begin{array}{c}\text { transformation } \\
\text { challenges assessment }\end{array}$ & - & & & & & \\
\hline & & market assessment & - & & & & & \\
\hline & assessment integration & & - & & & & & \\
\hline \multirow{5}{*}{ Pessl et al. (2020) [56] } & \multirow[t]{2}{*}{ analysis } & start workshop & $\begin{array}{l}\text { workshops } \\
\text { SWOT analysis }\end{array}$ & $\begin{array}{l}\text { management, } \\
\text { employees, external } \\
\text { experts }\end{array}$ & \multirow{5}{*}{$\begin{array}{l}\text { manufacturing } \\
\text { companies }\end{array}$} & \multirow{5}{*}{-} & \multirow{5}{*}{ - } & \multirow{5}{*}{$\begin{array}{c}\text { Austrian } \\
\text { manufacturing } \\
\text { company }\end{array}$} \\
\hline & & $\begin{array}{l}\text { I4.0 maturity } \\
\text { assessment }\end{array}$ & capability maturity models & & & & & \\
\hline & \multirow[t]{2}{*}{ targets } & define the target state & workshops & $\begin{array}{l}\text { interdisciplinary expert } \\
\text { teams }\end{array}$ & & & & \\
\hline & & $\begin{array}{l}\text { define and evaluate } \\
\text { measures }\end{array}$ & brainstorming, morphological analysis & & & & & \\
\hline & realization & prepare decisions & balanced Scorecard & & & & & \\
\hline \multirow{6}{*}{ Leone et al. (2020) [57] } & $\begin{array}{l}\text { I4.0 maturity } \\
\text { assessment }\end{array}$ & & questionnaires or interviews & $\begin{array}{l}\text { representatives of the } \\
\text { company departments }\end{array}$ & \multirow{6}{*}{$\begin{array}{c}\text { SME } \\
\text { manufacturing } \\
\text { companies }\end{array}$} & \multirow{6}{*}{-} & \multirow{6}{*}{ literature review } & \multirow{6}{*}{$\begin{array}{l}\text { pharmaceutica } \\
\text { company }\end{array}$} \\
\hline & process AS-IS analysis & & flow charts & $\begin{array}{c}\text { managers and } \\
\text { operators }\end{array}$ & & & & \\
\hline & \multirow{4}{*}{ I4.0 roadmap design } & $\begin{array}{c}\text { company flow } \\
\text { assessment }\end{array}$ & workshop and design thinking approach & \multirow{4}{*}{$\begin{array}{l}\text { main internal } \\
\text { stakeholders }\end{array}$} & & & & \\
\hline & & $\begin{array}{c}\text { project definition and } \\
\text { evaluation }\end{array}$ & analytical hierarchy process (AHP) & & & & & \\
\hline & & roadmap elaboration & Roadmap & & & & & \\
\hline & & $\begin{array}{l}\text { overall project review } \\
\text { and balancing }\end{array}$ & & & & & & \\
\hline
\end{tabular}


Table 4. Cont.

\begin{tabular}{|c|c|c|c|c|c|c|c|}
\hline Authors & Description/Phases & Tools and Methods & Involved Stakeholders & Focus & $\begin{array}{l}\text { Theoretical } \\
\text { Approach }\end{array}$ & Development & Test \\
\hline \multirow{9}{*}{ Butt (2020) [58] } & process identification & $\begin{array}{c}\text { stakeholder map } \\
\text { SWOT } \\
\text { analysis } \\
\text { organizational chart } \\
\text { context } \\
\text { diagram } \\
\text { business use-case diagram }\end{array}$ & \multirow{9}{*}{$\begin{array}{l}\text { internal (employees) } \\
\text { and external } \\
\text { (customers) } \\
\text { stakeholders }\end{array}$} & \multirow{9}{*}{$\begin{array}{l}\text { manufacturing } \\
\text { companies }\end{array}$} & \multirow{9}{*}{$\begin{array}{l}\text { business process } \\
\text { management }\end{array}$} & \multirow{9}{*}{ literature review } & \multirow{9}{*}{ - } \\
\hline & process discovery & $\begin{array}{l}\text { process flow chart } \\
\text { value-stream map }\end{array}$ & & & & & \\
\hline & process redesign & $\begin{array}{l}\text { simulation tools } \\
\text { Pugh matrix }\end{array}$ & & & & & \\
\hline & streamlining business processes & - & & & & & \\
\hline & risk management & $\begin{array}{l}\text { brainstorming } \\
\text { risk register }\end{array}$ & & & & & \\
\hline & skill gap analysis & - & & & & & \\
\hline & change management & $\begin{array}{l}\text { ADKAR model, Lewin's change } \\
\text { management model, Kotter's change } \\
\text { management model }\end{array}$ & & & & & \\
\hline & process validation and implementation & & & & & & \\
\hline & process monitoring and control & lean six-sigma approach & & & & & \\
\hline \multirow{6}{*}{$\begin{array}{l}\text { Capgemini's six-step } \\
\text { journey towards } \\
\text { Industry 4.0. (2014) [59] }\end{array}$} & conduct a digital maturity assessment & & & \multirow{6}{*}{$\begin{array}{l}\text { manufacturing } \\
\text { companies }\end{array}$} & \multirow{6}{*}{-} & \multirow{6}{*}{$\begin{array}{l}\text { experience in } \\
\text { digital } \\
\text { transformation } \\
\text { projects }\end{array}$} & \multirow{6}{*}{$\begin{array}{l}\text { not explicitly } \\
\text { indicated }\end{array}$} \\
\hline & $\begin{array}{c}\text { identify the opportunities and threats in I4.0 } \\
\text { environment }\end{array}$ & & & & & & \\
\hline & define I4.0 vision and strategy & & - & & & & \\
\hline & prioritize digital transformation domain & & & & & & \\
\hline & derive the roadmap towards I4.0 & & & & & & \\
\hline & implement and sustain the change & & & & & & \\
\hline \multirow{7}{*}{$\begin{array}{l}\text { Accenture's digital } \\
\text { transformation journey } \\
\text { (2014) [60] }\end{array}$} & broaden the definition of digital & & \multirow{7}{*}{ customers } & \multirow{7}{*}{-} & \multirow{7}{*}{-} & \multirow{7}{*}{$\begin{array}{l}\text { experience in } \\
\text { digital } \\
\text { transformation } \\
\text { projects }\end{array}$} & \multirow{7}{*}{$\begin{array}{l}\text { not explicitly } \\
\text { indicated }\end{array}$} \\
\hline & discover how in love customers really are & & & & & & \\
\hline & build momentum from the top & & & & & & \\
\hline & teach the power of digital & & & & & & \\
\hline & encourage digital accountability & & & & & & \\
\hline & commit to never being satisfied & & & & & & \\
\hline & invest beyond the here and now & & & & & & \\
\hline
\end{tabular}


Table 4. Cont.

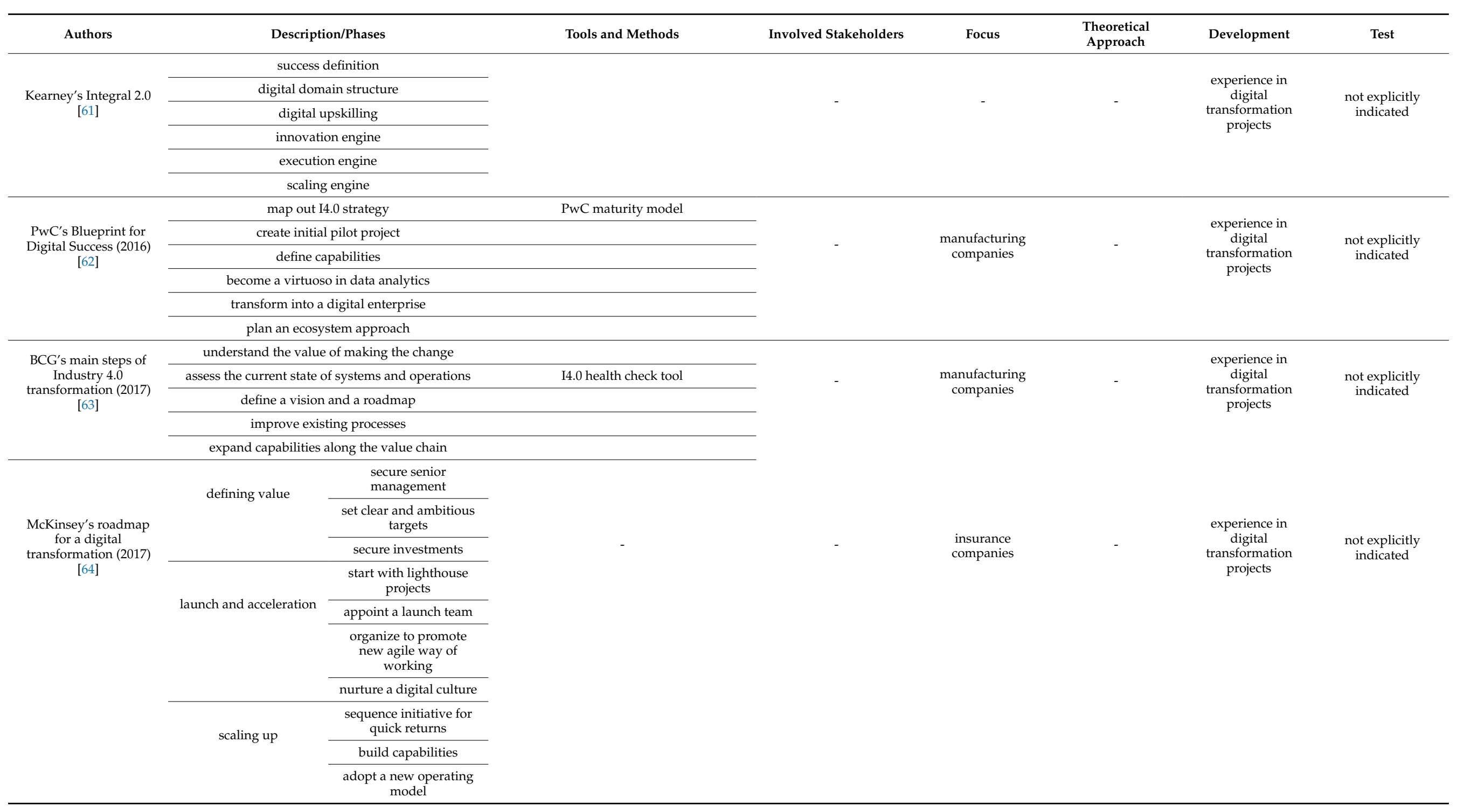


Table 4. Cont.

\begin{tabular}{|c|c|c|c|c|c|c|c|}
\hline Authors & Description/Phases & Tools and Methods & Involved Stakeholders & Focus & $\begin{array}{l}\text { Theoretical } \\
\text { Approach }\end{array}$ & Development & Test \\
\hline \multirow{3}{*}{$\begin{array}{l}\text { Deloitte digital } \\
\text { industrial } \\
\text { transformation } \\
\text { framework [65] }\end{array}$} & strategy & \multirow{3}{*}{-} & \multirow{3}{*}{-} & \multirow{3}{*}{$\begin{array}{l}\text { manufacturing } \\
\text { companies }\end{array}$} & \multirow{3}{*}{-} & \multirow{3}{*}{$\begin{array}{l}\text { experience in } \\
\text { digital } \\
\text { transformation } \\
\text { projects }\end{array}$} & \multirow{3}{*}{$\begin{array}{c}\text { not explicitly } \\
\text { indicated }\end{array}$} \\
\hline & business model & & & & & & \\
\hline & operating model & & & & & & \\
\hline \multirow{6}{*}{$\begin{array}{c}\text { McKinsey's six } \\
\text { building block of } \\
\text { digital transformation } \\
\text { (2021) [66] }\end{array}$} & creating a business-led technology road map & \multirow{6}{*}{-} & \multirow{6}{*}{-} & \multirow{6}{*}{$\begin{array}{l}\text { manufacturing } \\
\text { companies }\end{array}$} & \multirow{6}{*}{-} & \multirow{6}{*}{$\begin{array}{l}\text { experience in } \\
\text { digital } \\
\text { transformation } \\
\text { projects }\end{array}$} & \multirow{6}{*}{$\begin{array}{l}\text { not explicitly } \\
\text { indicated }\end{array}$} \\
\hline & developing and upskilling talent & & & & & & \\
\hline & adopting an agile delivery methodology & & & & & & \\
\hline & shifting to a modern technology environment & & & & & & \\
\hline & focusing on data management and enrichment & & & & & & \\
\hline & $\begin{array}{c}\text { driving the adoption and scaling of digital } \\
\text { initiatives }\end{array}$ & & & & & & \\
\hline
\end{tabular}




\subsection{DTMs under the Lens of Change Management}

As already mentioned, we used change management as methodological lens to analyse the DTMs. To do so, we first contextualized the change management activities listed in Table 2 to the case of a specific change, i.e., the one associated to digital transformation for I4.0 transition (Table 5). In this way, we are able to investigate whether and to what extent DTMs take into account the lessons learnt in the field of change management. The list is also useful to compare the phases proposed in the different DTMs. As the phases are quite diverse-at least by considering the way they are named - without such a list the comparison would have been harder.

Table 5. List of digital transformation activities based on change management approach.

\begin{tabular}{|c|c|}
\hline Change Management Activities & Digital Transformation Activities \\
\hline define a strong leadership & define a strong leadership \\
\hline \multirow{3}{*}{ generate awareness on the need for change } & $\begin{array}{l}\text { analyse I } 4.0 \text { environment to identify } \\
\text { opportunities and threats }\end{array}$ \\
\hline & conduct a digital maturity assessment \\
\hline & $\begin{array}{l}\text { generate awareness on the need for I } 4.0 \\
\text { transition }\end{array}$ \\
\hline define a clear change vision and strategy & $\begin{array}{l}\text { define a clear vision, a strategy and a roadmap } \\
\text { for the I. } 0 \text { transition }\end{array}$ \\
\hline communicate change vision and strategy & $\begin{array}{l}\text { communicate the vision, strategy and roadmap } \\
\text { for the I } 4.0 \text { transition }\end{array}$ \\
\hline define a change management team & define an I4.0 change management team \\
\hline $\begin{array}{l}\text { identify short-term goals and pilot projects to } \\
\text { test the change }\end{array}$ & $\begin{array}{l}\text { identify short terms goals and pilot projects of } \\
\text { digitalization }\end{array}$ \\
\hline identify and manage resistance to change & identify and manage resistance to change \\
\hline \multirow{2}{*}{ train people } & define digital capabilities and skills \\
\hline & train and/or recruit people \\
\hline $\begin{array}{l}\text { collect and analyse feedbacks and monitor } \\
\text { change }\end{array}$ & $\begin{array}{l}\text { collect and analyse feedbacks and monitor } \\
\text { the digital transformation process }\end{array}$ \\
\hline $\begin{array}{l}\text { celebrate success and implement corrective } \\
\text { actions }\end{array}$ & $\begin{array}{l}\text { celebrate success and implement corrective } \\
\text { actions }\end{array}$ \\
\hline consolidate the change & consolidate the change \\
\hline
\end{tabular}

In the comparison of the existing DTMs under the lens of change management, we considered only the change management activities that each model explicitly includes. Results of the comparison are reported in Table 6 (for the DTMs retrieved from grey literature) and Table 7 (for the DTMs retrieved from academic literature). 
Table 6. Comparison of consulting firms' DTMs under the lens of change management.

\begin{tabular}{|c|c|c|c|c|c|c|c|c|}
\hline $\begin{array}{c}\text { Digital } \\
\text { Transformation } \\
\text { Activities }\end{array}$ & $\begin{array}{c}\text { Capgemini's } \\
\text { Six-Step } \\
\text { Journey } \\
\text { towards } \\
\text { Industry } 4.0\end{array}$ & $\begin{array}{l}\text { Accenture's } \\
\text { Digital Trans- } \\
\text { formation } \\
\text { Journey }\end{array}$ & $\begin{array}{c}\text { Kearney's } \\
\text { Integral } 2.0\end{array}$ & $\begin{array}{c}\text { PwC's } \\
\text { Blueprint for } \\
\text { Digital } \\
\text { Success }\end{array}$ & $\begin{array}{l}\text { BCG's Main } \\
\text { Steps of } \\
\text { Industry } 4.0 \\
\text { Transforma- } \\
\text { tion }\end{array}$ & $\begin{array}{l}\text { McKinsey's } \\
\text { Roadmap for } \\
\text { a Digital } \\
\text { Transforma- } \\
\text { tion }\end{array}$ & $\begin{array}{c}\text { Deloitte Digi- } \\
\text { talIndustrial } \\
\text { Transforma- } \\
\text { tion } \\
\text { Framework }\end{array}$ & $\begin{array}{c}\text { McKinsey's } \\
\text { Six Building } \\
\text { Block of } \\
\text { Digital Trans- } \\
\text { formation }\end{array}$ \\
\hline $\begin{array}{l}\text { Define a } \\
\text { strong } \\
\text { leadership }\end{array}$ & $\bullet 1$ & $\bullet$ & & $\bullet$ & $\bullet$ & • & & $\bullet$ \\
\hline $\begin{array}{l}\text { Analyse I4.0 } \\
\text { environment } \\
\text { to identify } \\
\text { opportunities } \\
\text { and threats }\end{array}$ & $\bullet$ & & & & $\bullet$ & & & \\
\hline $\begin{array}{l}\text { Conduct a } \\
\text { digital } \\
\text { maturity } \\
\text { assessment }\end{array}$ & $\bullet$ & & & • & $\bullet$ & & & \\
\hline \multicolumn{9}{|l|}{$\begin{array}{c}\text { Generate } \\
\text { awareness on } \\
\text { the need for } \\
\text { I4.0 transition }\end{array}$} \\
\hline $\begin{array}{l}\text { Define a clear } \\
\text { vision, a } \\
\text { strategy and a } \\
\text { roadmap for } \\
\text { the I4.0 } \\
\text { transition }\end{array}$ & $\bullet$ & & $\bullet$ & $\bullet$ & $\bullet$ & $\bullet$ & $\bullet$ & $\bullet$ \\
\hline $\begin{array}{l}\text { Communicate } \\
\text { the vision, } \\
\text { strategy and } \\
\text { roadmap for } \\
\text { the I4.0 } \\
\text { transition }\end{array}$ & $\bullet$ & & & & $\bullet$ & $\bullet$ & $\bullet$ & \\
\hline $\begin{array}{l}\text { Define a I4.0 } \\
\text { change } \\
\text { management } \\
\text { team }\end{array}$ & & & $\bullet$ & $\begin{array}{l}\bullet \\
\text { (only for pilot } \\
\text { project) }\end{array}$ & & • & $\bullet$ & \\
\hline $\begin{array}{c}\text { Identify short } \\
\text { terms goals } \\
\text { and } \\
\text { pilot projects } \\
\text { of } \\
\text { digitalization }\end{array}$ & $\bullet$ & & $\bullet$ & $\bullet$ & $\bullet$ & $\bullet$ & & $\bullet$ \\
\hline \multicolumn{9}{|l|}{$\begin{array}{l}\text { Identify and } \\
\text { manage } \\
\text { resistance to } \\
\text { change }\end{array}$} \\
\hline $\begin{array}{c}\text { Define digital } \\
\text { capabilities } \\
\text { and skills }\end{array}$ & & & & • & & $\bullet$ & $\bullet$ & $\bullet$ \\
\hline $\begin{array}{l}\text { Train and/or } \\
\text { recruit people }\end{array}$ & & $\bullet$ & $\bullet$ & • & & $\bullet$ & $\bullet$ & $\bullet$ \\
\hline $\begin{array}{l}\text { Collect and } \\
\text { analyse } \\
\text { feedbacks and } \\
\text { monitor the } \\
\text { digital trans- } \\
\text { formation } \\
\text { process }\end{array}$ & & $\bullet$ & & & & & & \\
\hline $\begin{array}{l}\text { Celebrate } \\
\text { success and } \\
\text { implement } \\
\text { corrective } \\
\text { actions }\end{array}$ & & $\bullet$ & & & & & & \\
\hline $\begin{array}{l}\text { Consolidate } \\
\text { the change }\end{array}$ & $\bullet$ & & & & & • & & \\
\hline
\end{tabular}

${ }^{1}$ The dots indicate the activities included in each model. 
Table 7. Comparison of DTMs retrieved from the academic literature under the lens of change management.

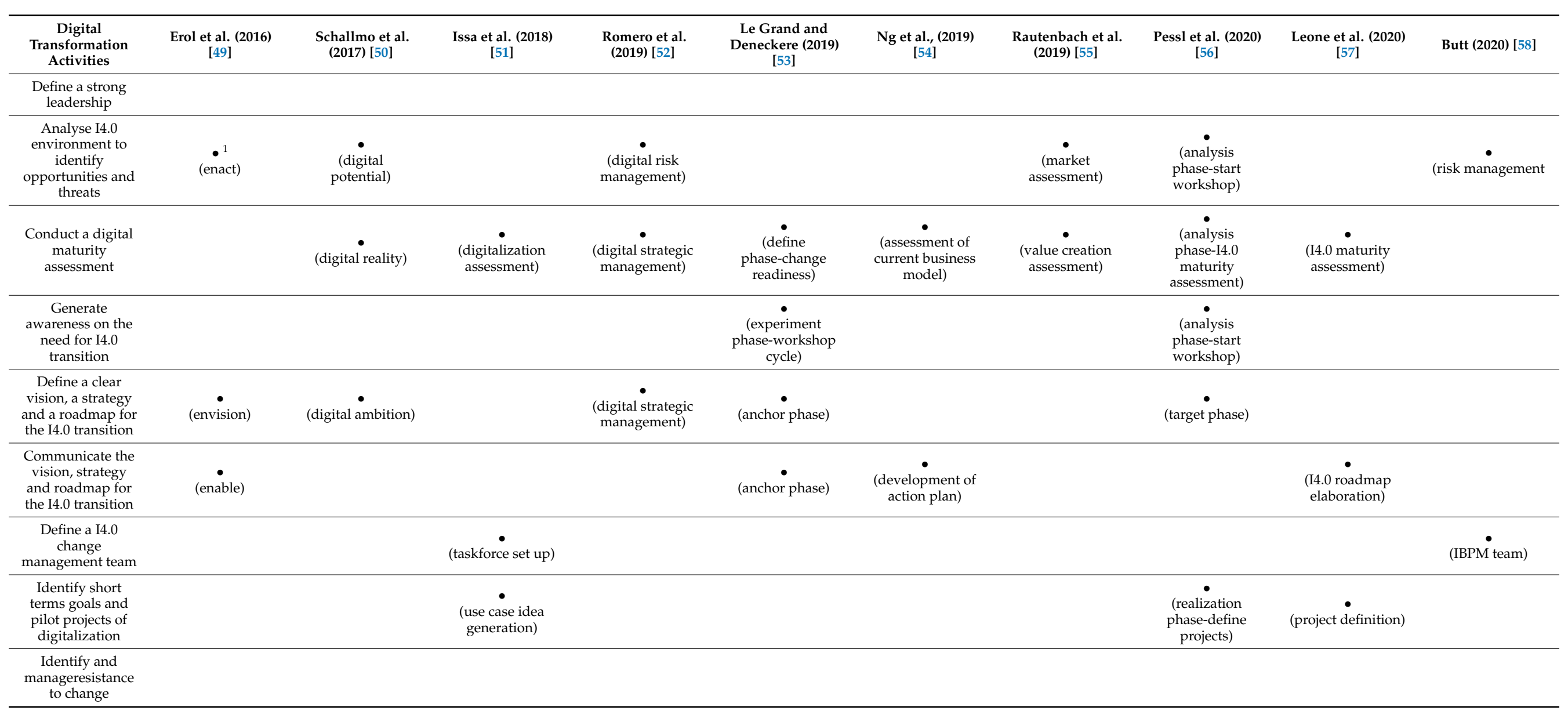


Table 7. Cont.

\begin{tabular}{|c|c|c|c|c|c|c|c|c|c|c|}
\hline $\begin{array}{c}\text { Digital } \\
\text { Transformation } \\
\text { Activities }\end{array}$ & $\begin{array}{c}\text { Erol et al. (2016) } \\
{[49]}\end{array}$ & $\begin{array}{l}\text { Schallmo et al. } \\
\text { (2017) [50] }\end{array}$ & $\begin{array}{c}\text { Issa et al. (2018) } \\
\text { [51] }\end{array}$ & $\begin{array}{l}\text { Romero et al. } \\
\text { (2019) [52] }\end{array}$ & $\begin{array}{c}\text { Le Grand and } \\
\text { Deneckere (2019) } \\
{[53]}\end{array}$ & $\begin{array}{c}\text { Ng et al., (2019) } \\
{[54]}\end{array}$ & $\begin{array}{l}\text { Rautenbach et al. } \\
\text { (2019) [55] }\end{array}$ & $\begin{array}{c}\text { Pessl et al. (2020) } \\
\text { [56] }\end{array}$ & $\begin{array}{c}\text { Leone et al. (2020) } \\
\text { [57] }\end{array}$ & Butt (2020) [58] \\
\hline $\begin{array}{l}\text { Define digital } \\
\text { capabilities and } \\
\text { skills }\end{array}$ & & $\begin{array}{c}\bullet \\
\text { (digital } \\
\text { implementation) }\end{array}$ & & $\begin{array}{c}\stackrel{\bullet}{\text { digital strategic }} \\
\text { management) }\end{array}$ & & $\begin{array}{l}\text { (assessment of } \\
\text { current digital } \\
\text { capabilities and } \\
\text { identification of } \\
\text { future ones) }\end{array}$ & $\begin{array}{c}\bullet \\
\text { (digital capability } \\
\text { maturity } \\
\text { assessment) }\end{array}$ & & & $\begin{array}{l}\text { (skills gap } \\
\text { analysis) }\end{array}$ \\
\hline $\begin{array}{l}\text { Train and/or } \\
\text { recruit people }\end{array}$ & & & & & $\begin{array}{c}\bullet \\
\text { (experiment } \\
\text { phase-workshops } \\
\text { and formative } \\
\text { cycle) }\end{array}$ & & & & & \\
\hline $\begin{array}{c}\text { Collect and } \\
\text { analyse feedbacks } \\
\text { and monitor the } \\
\text { digital } \\
\text { transformation } \\
\text { process }\end{array}$ & & & & & $\begin{array}{c}\bullet \\
\text { (experiment } \\
\text { phase-control } \\
\text { cycle) }\end{array}$ & & & & & $\begin{array}{c}\text { (process } \\
\text { monitoring and } \\
\text { control) }\end{array}$ \\
\hline \multicolumn{11}{|l|}{$\begin{array}{l}\text { Celebrate success } \\
\text { and implement } \\
\text { corrective actions }\end{array}$} \\
\hline
\end{tabular}

${ }^{1}$ The dots indicate the activities included in each model. 
Most DTMs provided by consulting firms highlight the importance of leadership to drive a digital transformation initiative; although this aspect is a key features of change management, it is not mentioned in any of DTMs retrieved from the academic literature.

Most DTMs, especially those provided by scholars, involve the activity "conducting a digital maturity assessment" as a central initial activity. This activity is also included in the DTMs developed by Capgemini, PwC and BCG. Also, the activity "analysis of I4.0 environment to identify opportunities and threats" is included in many DTMs; however, only two DTMs explicitly envisage the activity "generate awareness on the need for the I4.0 transition". Such an activity consists in sharing, with all stakeholders, the results of the conducted digital maturity assessment, as well as the best practices of digitalization and the opportunities derived from the digital transformation.

Most DTMs include an activity of definition of the vision and strategy towards I4.0 as well as the development of a digital roadmap to be communicated to all members of the organization.

From an organizational perspective, the DTMs provided by Issa et al. [51] and Butt [58] are the only academic models that envisage the creation of an ad-hoc task force to organize and manage the digital transformation initiative. Such an activity is considered relevant in the change management literature. Among the DTMs developed by consulting firms, PwC suggests the setting-up of a team dedicated to managing pilot projects only; also the DTMs developed by Kearney [61], McKinsey [64] and Deloitte [65] envisage the creation of a team dedicated to managing the digital transformation journey; in particular, the McKinsey model [64] also defines the experts (e.g., designers, data scientists, scrum masters and developers) that the launch team should include to lead the digital transformation in the insurance sector. The Deloitte DTM [65] suggests creating cross-functional transformation teams to manage the transformation.

Only a few DTMs retrieved from the academic literature propose conducting pilot projects $[51,56,57]$. Pilot projects are useful for testing digital solutions in specific contexts before the full-scale implementation of digital solution. Most consulting firms' DTMs propose such a step. Among them, McKinsey's DTMs [64,66] also suggest adopting an agile methodology to implement digital solutions to create an environment that makes faster testing new technologies and, then, to iteratively make improvements based on feedbacks and insights gleaned from the field. The development of pilot projects and the identification of short-terms goals is a key aspect of change management, as it is considered a way to test the change before the wider rollout of the change, as well as to motivate people more reluctant to change. Some consulting firms (e.g., the BCG's DTM [63] and the McKinsey's DTM [64]) suggest the creation of digital units, namely digital divisions-often separated from the rest of the organization-where the digital solutions and the new ways of working are tested to evaluate their potential impacts before scaling up.

A specific step to analyse and define digital skills and capabilities is included in many consulting firms' DTMs, namely the PwC [62], Deloitte [65] and McKinsey [64,66] DTMs: these models highlight the essential role of digital skills in a successful digital transformation. They recommend that companies assess and map the digital capabilities needed to enable digital transformation and also suggest methods to create and acquire those capabilities that are not internally available; to this end, PwC's [62] and McKinsey's [64,66] DTMs suggest employee upskilling through dedicated digital training programs, as well as external recruitment to hire others' capabilities; Deloitte [65], beside the methods suggested by McKinsey and $\mathrm{PwC}_{w}$, suggests the creation of partnership and recruitment as-a-service to access the needed capabilities. Some DTMs retrieved from the academic literature mention such an aspect, but they essentially focus on the assessment of digital capabilities needed to implement a digital transformation, without suggesting any activity to overcome the digital gap. Only Le Grand et al. [53] suggest training programs to provide employees with the digital skills needed to successfully implement a digital transformation. 
The monitoring of change-which includes the collection of feedback from people involved in the change, the identification of gaps and problems and the implementation of corrective actions-is a key activity, in change management, to avoid failure. Le Grand et al. [53] include a step of monitoring change and suggest surveying individuals who are the beneficiaries of change as a means of evaluating change in progress. Butt [58] also envisages an activity of monitoring change and suggests adopting a lean six-sigma approach. Only the model proposed by Accenture envisages such an aspect, since it suggests setting digital key performance indicators for personnel in all areas of the organization to monitor their digital performance. Most retrieved DTMs retrieved do not include any change-monitoring activities, despite change management literature's considering it as essential to understand how and to what extent an introduced change is improving the organization's performance and to eventually implement corrective actions. The lack of activities devoted to the monitoring of change is one of the main limits of extant DTMs.

Another limitation of existing DTMs relates to the identification and management of the resistance to change; for the success of the change initiative, it is crucial that involved people accept the change. However, no DTM explicitly envisages activities devoted to identifying the resistance to change that inevitably arises when a new digital technology is introduced, nor provides any methods to address and manage it. Some consulting firms' DTMs include the celebration and reward of achieved successes as a way to encourage the acceptance of digital change; for instance, Accenture's DTM [60] envisages the assessment of specific key performance indicators and the rewarding of people who obtain better digital performances; the McKinsey DTM [64] refers to rewarding the success obtained in pilot projects.

Also, most DTMs do not include the activity "consolidate the change"; only a few consulting firms' DTMs envisage such an activity. In particular, the Capgemini DTM [59] suggests concrete actions to implement the digital roadmap and to integrate the digital change into the culture of the organization; Deloitte's [65] and McKinsey's [64] DTMs indicate the definition of a new operating business model to translate digital strategy into concrete action; that implies the definition of a completely new way of creating value, the definition of market segments and new products or services to be offered and how those offerings will be monetized. Other models (BCG's [63] and McKinsey's [66] DTMs) suggest the creation of new digital business processes, as well as the digitalization of existing ones, as a way to widely implement the digital change. The redesign and realignment of organizational structure is also explicitly indicated by the McKinsey DTM [64] as being critical to the successful implementation of digital transformation.

\section{Discussion}

Our study shows that the retrieved DTMs do not provide complete models to effectively support managers and organizations in all the phases of the digital transformation process. This confirms the results reported in [10]. Change management lessons are considered to a limited extent; only a few DTMs include the key activities proposed by change management models-e.g., "generate awareness on the need to change", "define a change management team", "identify short-term goals and test the change in pilot projects", "identify and manage resistance to change", "monitor change", "celebrate success and implement corrective actions".

The retrieved DTMs mainly focus on companies working in the manufacturing industry; only the model proposed by McKinsey [64] explicitly focuses on the insurance industry. Those developed in the academic context are mostly rooted in extant literature and were tested in real manufacturing contexts. Those developed by consulting firms are mostly derived from experience in real digital transformation projects and not based on theoretical approaches.

Based on the change management literature and comparison between the DTMs, some recommendations for overcoming DTMs' limitations are here reported: 
- A well-designed digital transformation initiative requires a strong commitment by the top management. Any initiative toward digital transformation must be undertaken by the top management, who must deeply study how the competitive environment is evolving, identify digital opportunities, threats and risks deriving from the introduction of digital technologies and clearly define how the organization intends to create value in the era of I4.0. Such aspects are so far taken into consideration mostly in the DTMs developed by consulting firms.

- To set up the goals of digital transformation, top management also must appraise the digital maturity level of the organization. Digital maturity assessment is a crucial activity in any digital transformation initiative, as it consists in determining the current level of digitalization of the organization and its readiness to introduce changes. In this phase, digital maturity-assessment models and tools [67-69] can be adopted; they consist in filling-out questionnaires by which an organization measures digital maturity indices. The results thereof highlight the areas and processes in which the organization presents an advanced level of digital maturity, as well as those presenting room for improvement; the digital maturity assessment makes the organization aware of its own digital gaps and reveals needs and priorities of its digital transformation. Workshops should be arranged to make the stakeholders aware of the need for digital change, share with them the digital maturity assessment results and depict the benefits stemming from the digital transformation.

- Top management also must clearly define a vision and a strategy for the transition to I4.0. Defining a vision means identifying the goals to be achieved by the digital transformation and envisioning what the organization wants to become; the digital strategy defines how these goals will be achieved. A roadmap to clearly detail the phases of the digital transformation initiative, as well as the time to implement each phase, should be developed. Also, the I4.0 vision, strategy and roadmap must be communicated and shared with all stakeholders involved in the digital transformation. Such an aspect is considered crucial in the change management literature.

- From an organizational perspective, top management should appoint a transition team, i.e., a task force, often temporary, having the clear and well-defined role of managing the digital transformation initiatives. The transition team should be composed of people from different functional areas and hierarchical levels, with a clear vision of the current organization's business processes.

- Another important recommendation concerns the definition and implementation of pilot projects. The transition team should identify selected processes to be digitalized, so as to test digital technologies before a wider rollout of such digital solutions, and to identify possible operational problems. Moreover, early successes effectively show the benefits of digital technologies and promote a willingness to change within the organization.

- The identification of resistance to change should also be included in a well-designed DTM; the transition team should identify resistance to change that may arise in the digital transformation and define a resistance-management plan to prevent and mitigate it. This plan may include activities, such as training programs to provide people with digital capabilities for operating in a new way, celebrating successes obtained in pilot projects and involving all people affected by the change-especially those more reluctant to change-and try to understand the reasons.

- The transition team must also operate to solve the capability gap that generally arises in the implementation of a digital transformation initiative. To address such a gap is often one of the main challenges in the transition of organizations towards the I4.0 paradigm. Some capabilities may be already available in the organization, others may be externally acquired or obtained via training initiatives. As mentioned, training is an essential activity to provide people with skills and competences in operating with new technologies and working methods, while avoiding resistance to change. Organizations often may struggle to obtain staff with the right skills; thus, they may 
need to build competences in-house. This might seem a daunting challenge, yet it offers a significant opportunity: giving people the opportunity to develop their own skills is also a powerful way of attracting and retaining talent [70].

- A monitoring phase should also be included. By questionnaires, interviews, or periodical surveys, feedbacks from people involved in the change should be collected and assessed, in view of understanding to what extent the introduction of digital technologies is improving processes' performances. By leveraging on possible critical issues and inefficiencies emerged in this phase, corrective actions must be implemented to avoid failure of the initiative. Successes must also be celebrated.

- A DTM should also include activities to consolidate the change, namely, to make the digital change an integral part of the organization's culture; the definition of a new digital business model, as well as the digitalization of exiting business processes and the definition of new digital processes, are activities suggested in implementing the digital change. Measures to realign the organizational structure to the new situation are indeed necessary.

Finally, we also suggest adopting a participatory and human-centric approach in managing a complex I4.0 transition. This means that the actors involved and affected by the change must be an active part in the definition and implementation of the digital transformation initiative. As mentioned, for example, by Checkland [71], the involved actors are essential in making "feasible and desirable" changes. Such a recommendation is coherent with the wider literature on sustainability, which is a key concept of the vision of future industry named "Industry 5.0" [72,73]. According to the European Commission, which has recently proposed it to complement and extend the I4.0 paradigm [72], industry has the power to achieve societal goals and provide prosperity by respecting the planet and placing the wellbeing of workers at the core of production processes [73]. The I5.0 vision is characterized by a shift of focus from a technology-driven approach to progress to a thoroughly human-centric one, in order to develop sustainable and resilient industry. Under such an approach, any technological transformation should be designed and managed according to human needs rather than being based on purely technical and economic perspectives. The paradigmatic transition characterizing I5.0 should be considered by DTMs aimed at supporting those organizations that want to successfully implement a digital transformation. All the activities we discussed and proposed for inclusion in a DTM for the transition towards the I4.0 paradigm are also valid for a DTM aimed at supporting companies' transition towards I5.0. Additional considerations are, however, needed. First, top management should clearly define a digital vision and strategy that, besides defining the goals to be achieved through digitalization from a technical and economic perspective, should also define environmental and social goals that the digital transformation intends to achieve. Additionally, a DTM for the transition toward I5.0 should be consistent with the human-centric approach inherent to I5.0. The participatory approach we suggest advances upon this direction. The change management approach alone could not be sufficient; change management, indeed, introduces changes in the organization and ensures that people adapt to such changes and that they accept them as they are; some activities, such as the communication of digital vision and strategy to people affected by the change, the celebration of achieved successes and the purely digital upskilling of employees, aim at managing the effects of a transition on the people involved, encouraging the acceptance of change, and mitigating the emergence of resistance to change. This aspect represents, in our view, the main gap in the change management literature. The adoption of a participatory approach allows companies to overcome such a limitation and makes the DTM also coherent with the model proposed by I5.0. Adopting a participatory and human-centric approach means that the digital transformation must be carried out through with the active involvement of all the actors affected by the digital change in all the phases of the digital transformation process, from the definition of digital vision and strategy to the digital redesign of business processes. A participatory approach facilitates the identification of changes that are feasible and desirable from the perspectives of the actors affected by 
the change, thereby preventing resistance to change and reducing the change initiative's risk of failure. Furthermore, the education and training of people involved in the digital transition may play a fundamental role in enabling them to successfully design and implement the digital change. To this aim, training programs should not deal only with digital skills (e.g., digital literacy, artificial intelligence, data analytics, cybersecurity [73]) but also with more transversal capabilities and skills, such as those related to creative problem solving, entrepreneurial capabilities, team working, effective communication and complexity management.

\section{Conclusions}

Companies are increasingly aware that, to compete in the new paradigm of I4.0, they must face the challenge of digital transformation [4,5]. However, the academic literature discusses the topic mainly with respect to technological aspects, whereas few studies have provided complete models for managing the business digital transformation $[9,10]$. Besides the contribution by academia, guidelines to manage the I4.0 transition have been developed by some consulting firms to support organizations involved in the digital transformation.

This paper investigated whether and to what extent extant digital transformation models (DTMs) consider the lessons learnt in the field of change management, a wellknown approach that allows organizations to successful manage any change initiative. To achieve such a goal, a systematic review of the literature was conducted. All retrieved DTMs were analysed under the lens of the change management literature.

Based on the research in this field and thanks to a comparison of the models there found, the limitations of existing DTMs were identified. Extant DTMs mainly address the digital transformation of manufacturing companies. Some DTMs included only the phases of I4.0 vision and strategy definition; other models included digital maturity assessments, as well as the implementation of pilot digitalization projects to test such change; no extant DTM included all the phases of the digital transformation process. Extant DTMs are not able to effectively support managers and companies in the digital transformation process, as they do not cover all the phases of the digital transformation process; generally, they mainly focus on the I4.0 definitions of vision, strategy and roadmaps, whereas little attention is devoted to the implementation and consolidation of digital change. Also, only few DTMs included the key activities proposed by change management models. Some recommendations, namely strong leadership, the identification of digital opportunities and threats, digital maturity assessments, defining and communicating I4.0 vision, strategy and roadmaps, the creation of a transition team, the implementation of pilot projects and the celebration of successes, the analysis of resistances and the creation of a resistance management plan, training, monitoring and consolidation stages, were, then, provided. Finally, we suggested participative approaches be considered within DTMs. Only in this way will the transition to I4.0 paradigm be both feasible for the organization and desirable to all the actors affected by the digital transformation.

This study contributes to improving the existing theoretical knowledge of methods and frameworks guiding organizations in their transitions towards I4.0. From an academic perspective, it contributes to identify limits of existing approaches and stress certain aspects that must be considered to addressing them, thereby suggesting future paths of investigation. From a managerial perspective, this study is useful for organizations interested in undertaking a digital transformation initiative; specifically, it may guide in their choice of DTM to adopt, and provide companies with suggestions useful in successfully managing a digital transformation initiative.

Author Contributions: Conceptualization, all authors; methodology, A.N. and N.B.; software use, A.N.; validation, all authors; formal analysis, all authors; data curation, A.N.; writing-original draft preparation, all authors; writing - review and editing, all authors; visualization, A.N.; supervision, P.P. and B.S. All authors have read and agreed to the published version of the manuscript.

Funding: This research received no external funding. 
Institutional Review Board Statement: Not applicable.

Informed Consent Statement: Not applicable.

Data Availability Statement: All academic contributions included in the review are available on the Scopus database (www.scopus.com) (accessed on 30 January 2021).

Conflicts of Interest: The authors declare no conflict of interest.

\section{References}

1. Kagermann, H. Change through digitization-Value creation in the age of Industry 4.0. In Management of Permanent Change; Springer Gabler: Wiesbaden, Germany, 2015; pp. 23-45.

2. Porter, M.E.; Heppelmann, J.E. How Smart, Connected Products Are Transforming Competition. Harv. Bus. Rev. 2015, 93, 96-114.

3. Lorenz, M.; Rüßmann, M.; Waldner, M. Industry 4.0: The Future of Productivity and Growth in Manufacturing Industries. 2015. Available online: https://www.bcg.com/it-it/publications/2015/engineered_products_project_business_industry_4_future_ productivity_growth_manufacturing_industries (accessed on 12 January 2021).

4. Burmeister, C.; Lüttgens, D.; Piller, F.T. Business Model Innovation for Industrie 4.0: Why the 'Industrial Internet' Mandates a New Perspective on Innovation. Die Unternehm, Swiss J. Bus. Res. Pract. 2016, 70, 124-152. [CrossRef]

5. Ibarra, D.; Ganzarain, J.; Igartua, J.I. Business model innovation through Industry 4.0: A review. In Proceedings of the 11th International Conference on Interdisciplinarity in Engineering, INTER-ENG 2017, Tirgu Mures, Romania, 5-6 October 2017; Volume 22, pp. 4-10. [CrossRef]

6. Balogun, J.; Hailey, V.H. Exploring Strategic Change; Prentice-Hall: London, UK, 2008.

7. Ewenstein, B.; Smith, W.; Sologar, A. Changing Change Management. McKinsey, Co.. Available online: https://www.mckinsey. com/featured-insights/leadership/changing-change-management (accessed on 20 December 2020).

8. Keenan, P.; Powell, K.; Kurstjens, H.; Shanahan, M.; Lewis, M.; Busetti, M. Changing Change Management: A Blueprint That Takes Hold. BCG. Available online: https://www.bcg.com/it-it/publications/2012/change-management-postmerger-integrationchanging-change-management (accessed on 20 December 2020).

9. Cimini, C.; Pinto, R.; Cavalieri, S. The business transformation towards smart manufacturing: A literature overview about reference models and research agenda. IFAC-PapersOnLine 2017, 50, 14952-14957. [CrossRef]

10. Bordeleau, F.-Ë.; Felden, C. Digitally transforming organisations: A review of change models of industry 4.0. In Proceedings of the 27th European Conference on Information Systems: Information Systems for a Sharing Society, ECIS 2019, Stockholm and Uppsala, Sweden, 8-14 June 2019.

11. Cummings, T.G.; Worley, C.G. Organization Development E Change, 9th ed.; South-Western Cengage Learning: Mason, OH, USA, 2009.

12. Burnes, B. Managing Change: A Strategic Approach to Organisational Dynamics; Pearson Education: London, UK, 2004.

13. Senior, B.; Fleming, J. Organizational Change; Pearson Education: London, UK, 2006.

14. Moran, J.W.; Brightman, B.K. Leading organizational change. J. Work. Learn. 2000, 12, 66-74. [CrossRef]

15. Creasey, T. An Introduction to Change Management. 2018. Available online: https://www.prosci.com/hubfs/367443/2 .downloads/ebooks / An-Introduction-Guide-to-Change-Management-guide.pdf?hsLang=en-ca (accessed on 7 February 2021).

16. Lewin, K. Field Theory in Social Science: Selected Theoretical Papers; Harper\& Row: New York, NY, USA, 1951.

17. Kotter, J.P. Leading Change: Why Transformation Efforts Fail. Harv. Bus. Rev. 1996, 86, 59-67.

18. Overview of GE's Change Acceleration Process (CAP). 2009. Available online: https://bvonderlinn.wordpress.com/2009/01/25 / overview-of-ges-change-acceleration-process-cap/ (accessed on 20 January 2020).

19. Polk, J.D. Lean Six Sigma, innovation, and the change acceleration process can work together. Physician Exec. $2011,37,38-42$.

20. Prosci. Prosci Change Management Methodology. Available online: https://www.prosci.com/adkar/change-managementmethodology-overview (accessed on 17 November 2021).

21. Armstrong, M. A Handbook of Human Resource Management Practice, 10th ed.; Kogan Page Publishers: London, UK, 2006.

22. Denyer, D.; Tranfield, D. Producing a systematic review. In The Sage Handbook of Organizational Research Methods; Sage Publications Ltd.: Thousand Oaks, CA, USA, 2009; pp. 671-689.

23. Tranfield, D.; Denyer, D.; Smart, P. Towards a Methodology for Developing Evidence-Informed Management Knowledge by Means of Systematic Review. Br. J. Manag. 2003, 14, 207-222. [CrossRef]

24. Schumacher, A.; Erol, S.; Sihn, W. A Maturity Model for Assessing Industry 4.0 Readiness and Maturity of Manufacturing Enterprises. In Proceedings of the 6th International Conference on Changeable, Agile, Reconfigurable and Virtual Production, CARV 2016, Bath, UK, 4-6 September 2016; Volume 52, pp. 161-166. [CrossRef]

25. De Carolis, A.; Macchi, M.; Negri, E.; Terzi, S. A maturity model for assessing the digital readiness of manufacturing companies. In Proceedings of the Advances in Production Management Systems. The Path to Intelligent, Collaborative and Sustainable Manufacturing. APMS 2017. IFIP International Conference on Advances in Production Management Systems, Hamburg, Germany, 3-7 September 2017; Volume 513, pp. 13-20. [CrossRef]

26. Canetta, L.; Barni, A.; Montini, E. Development of a Digitalization Maturity Model for the Manufacturing Sector. In Proceedings of the 2018 IEEE International Conference on Engineering, Technology and Innovation, ICE/ITMC 2018, Stuttgart, Germany, 17-20 June 2018; pp. 1-7. [CrossRef] 
27. Azevedo, A.; Santiago, S.B. Design of an assessment industry 4.0 maturity model: An application to manufacturing company. In Proceedings of the International Conference on Industrial Engineering and Operations Management, Toronto, ON, Canada, 23-25 October 2019; pp. 208-217.

28. Nick, G.; Szaller, Á.; Várgedo, T. CCMS Model: A novel approach to digitalization level assessment for manufacturing companies. In Proceedings of the 16th European Conference on Management, Leadership and Governance, ECMLG 2020, Oxford, UK, 26-27 October 2020; pp. 195-203.

29. Mittal, S.; Romero, D.; Wuest, T. Towards a smart manufacturing maturity model for SMEs (SM3E). In Proceedings of the Advances in Production Management Systems. Smart Manufacturing for Industry 4.0. APMS 2018. IFIP Advances in Information and Communication Technology, Seoul, Korea, 26-30 August 2018; Volume 536, pp. 155-163. [CrossRef]

30. Rauch, E.; Unterhofer, M.; Rojas, R.A.; Gualtieri, L.; Woschank, M.; Matt, D.T. A maturity level-based assessment tool to enhance the implementation of industry 4.0 in small and medium-sized enterprises. Sustainability 2020, 12, 3559. [CrossRef]

31. Isaev, E.A.; Korovkina, N.L.; Tabakova, M.S. Evaluation of the readiness of a company's IT department for digital business transformation. Bus. Inform. 2018, 55-64. [CrossRef]

32. Gollhardt, T.; Halsbenning, S.; Hermann, A.; Karsakova, A.; Becker, J. Development of a Digital Transformation Maturity Model for IT Companies. In Proceedings of the 2020 IEEE 22nd Conference on Business Informatics (CBI), Antwerp, Belgium, 22-24 June 2020; Volume 1, pp. 94-103. [CrossRef]

33. Büyük, A.M.; Ateş, G.; Burghli, S.; Yılmaz, D. Digital Maturity Assessment Model for Smart Agriculture. In The International Symposium for Production Research; Springer: Cham, Switzerland, 2020; Volume 1, pp. 289-301. [CrossRef]

34. Facchini, F.; Digiesi, S.; Mossa, G.; Mummolo, G. Evaluating the I4.0 transformation readiness of agri-food companies: From factories to 'smart' factories. In Proceedings of the Summer School Francesco Turco, Palermo, Italy, 12-14 September 2018.

35. Zoubek, M.; Simon, M. Methodology for evaluating the readiness of internal logistics processes for Industry 4.0. In Proceedings of the IOP Conference Series: Materials Science and Engineering, Chennai, India, 16-17 September 2020; Volume 947. [CrossRef]

36. Facchini, F.; Olésków-Szłapka, J.; Ranieri, L.; Urbinati, A. A maturity model for logistics 4.0: An empirical analysis and a roadmap for future research. Sustainability 2020, 12, 86. [CrossRef]

37. Acerbi, F.; Assiani, S.; Taisch, M. A Methodology to Assess the Skills for an Industry 4.0 Factory. In Proceedings of the IFIP WG 5.7 International Conference on Advances in Production Management Systems, APMS 2019, Austin, TX, USA, 1-5 September 2019; Volume 567, pp. 520-527. [CrossRef]

38. Aguiar, T.; Gomes, S.B.; Da Cunha, P.R.; Da Silva, M.M. Digital transformation capability maturity model framework. In Proceedings of the 2019 IEEE 23rd International Enterprise Distributed Object Computing Conference (EDOC), Paris, France, 28-31 October 2019; pp. 51-57. [CrossRef]

39. Hizam-Hanafiah, M.; Soomro, M.A.; Abdullah, N.L. Industry 4.0 readiness models: A systematic literature review of model dimensions. Information 2020, 11, 364. [CrossRef]

40. Hizam-Hanafiah, M.; Soomro, M.A.; Abdullah, N.L.; Jusoh, M.S. Change readiness as a proposed dimension for industry 4.0 readiness models. Logforum 2021, 17, 83-96. [CrossRef]

41. Dikhanbayeva, D.; Shaikholla, S.; Suleiman, Z.; Turkyilmaz, A. Assessment of industry 4.0 maturity models by design principles. Sustainability 2020, 12, 9927. [CrossRef]

42. Hajoary, P.K. Industry 4.0 Maturity and Readiness Models: A Systematic Literature Review and Future Framework. Int. J. Innov. Technol. Manag. 2021, 17, 2030005. [CrossRef]

43. Mittal, S.; Khan, M.A.; Romero, D.; Wuest, T. A critical review of smart manufacturing \& Industry 4.0 maturity models: Implications for small and medium-sized enterprises (SMEs). J. Manuf. Syst. 2018, 49, 194-214. [CrossRef]

44. Demircan Keskin, F. A two-stage fuzzy approach for Industry 4.0 project portfolio selection within criteria and project interdependencies context. J. Multi-Criteria Decis. Anal. 2020, 27, 65-83. [CrossRef]

45. Hamzeh, R.; Zhong, R.; Xu, X.W.; Kajati, E.; Zolotova, I. A technology selection framework for manufacturing companies in the context of industry 4.0. In Proceedings of the 1st IEEE World Symposium on Digital Intelligence for Systems and Machines, DISA, Kosice, Slovakia, 23-25 August 2018; pp. 267-276. [CrossRef]

46. Richard, S.; Pellerin, R.; Bellemare, J.; Perrier, N. A business process and portfolio management approach for Industry 4.0 transformation. Bus. Process Manag. J. 2021, 27, 505-528. [CrossRef]

47. Guzmán, V.E.; Muschard, B.; Gerolamo, M.; Kohl, H.; Rozenfeld, H. Characteristics and Skills of Leadership in the Context of Industry 4.0. Procedia Manuf. 2020, 43, 543-550. [CrossRef]

48. von Ohain, B.P. Leader attributes for successful digital transformation. In Proceedings of the ICIS Conference Proceedings, Ponorogo, Indonesia, 27-28 October 2020.

49. Erol, S.; Schumacher, A.; Sihn, W. Strategic guidance towards Industry 4.0-A three-stage process model. In Proceedings of the International conference on competitive manufacturing, COMA, Stellenbosch, South Africa, 27-29 January 2016; pp. 495-501.

50. Schallmo, D.; Williams, C.A.; Boardman, L. Digital transformation of business models-best practice, enablers, and roadmap. Int. J. Innov. Manag. 2017, 21, 119-138. [CrossRef]

51. Issa, A.; Hatiboglu, B.; Bildstein, A.; Bauernhansl, T. Industrie 4.0 roadmap: Framework for digital transformation based on the concepts of capability maturity and alignment. In Proceedings of the 51st CIRP Conference on Manufacturing Systems, CIRP CMS 2018, Stockholm, Sweden, 16-18 May 2018; Volume 72, pp. 973-978. [CrossRef] 
52. Romero, D.; Flores, M.; Herrera, M.; Resendez, H. Five Management Pillars for Digital Transformation Integrating the Lean Thinking Philosophy. In Proceedings of the 25th IEEE International Conference on Engineering, Technology and Innovation, ICE/ITMC 2019, Sophia Antipolis, Valbonne, France, 17-19 June 2019; pp. 1-8. [CrossRef]

53. Le Grand, T.; Deneckere, R. COOC: An Agile Change Management Method. In Proceedings of the 21st IEEE Conference on Business Informatics, CBI 2019, Moscow, Russia, 15-17 July 2019; Volume 2, pp. 28-37. [CrossRef]

54. Ng, H.Y.; Tan, P.S.; Lim, Y.G. Methodology for Digitalization-A Conceptual Model. In Proceedings of the 2018 IEEE International Conference on Industrial Engineering and Engineering Management (IEEM), Bangkok, Thailand, 16-19 December 2019; pp. 1269-1273. [CrossRef]

55. Rautenbach, W.J.; Kock, I.D.; Jooste, J.L. The development of a conceptual model for enabling a value-adding digital transformation: A conceptual model that aids organisations in the digital transformation process. In Proceedings of the 2019 IEEE International Conference on Engineering, Technology and Innovation (ICE/ITMC), Sophia-Antipolis, Valbonne, France, 17-19 June 2019; pp. 1-10. [CrossRef]

56. Pessl, E.; Sorko, S.R.; Mayer, B. Roadmap industry 4.0-Implementation guideline for enterprises. In Proceedings of the 26th International Association for Management of Technology Conference, IAMOT, Vienna, Austria, 14-18 May 2017; Volume 5, pp. 193-202.

57. Leone, D.; Barni, A. Industry 4.0 on Demand: A Value Driven Methodology to Implement Industry 4.0. In Proceedings of the IFIP International Conference Advances in Information and Communication Technology, Novi Sad, Serbia, 30 August-3 September 2020; Volume 591, pp. 99-106. [CrossRef]

58. Butt, J. A conceptual framework to support digital transformation in manufacturing using an integrated business process management approach. Designs 2020, 4, 17. [CrossRef]

59. Bechtold, J.; Kern, A.; Lauenstein, C.; Bernhofer, L. Industry 4.0-The Capgemini Consulting View. Capgemini Consulting. Available online: https:/ / www.capgemini.com/consulting/wp-content/uploads/sites/30/2017/07/capgemini-consultingindustrie-4.0_0_0.pdf (accessed on 18 November 2021).

60. Shah, B.; Roytman, A.; De Matteis, P. Accenture Interactive-Point of View Series Digital Transformation Re-Imagine from the outside-In. Available online: https://www.accenture.com/t20160128t000639_w__/us-en/_acnmedia/accenture/ conversion-assets/dotcom/documents/global/pdf/technology_7/accenture-interactive-digital-transformation.pdf (accessed on 18 November 2021).

61. Strategic Digital Transformation-Kearney. Available online: https://www.kearney.com/digital/strategic-digital-transformation (accessed on 27 October 2021).

62. Reinhard, G.; Jesper, V.; Stefan, S. Industry 4.0: Building the Digital Enterprise. PwC. Available online: https://www.pwc.com/ $\mathrm{gx} / \mathrm{en} /$ industries/industries-4.0/landing-page/industry-4.0-building-your-digital-enterprise-april-2016.pdf (accessed on 18 November 2021).

63. Brunelli, J.; Lukic, V.; Milon, T. Five Lessons from the Frontlines of Industry 4.0. Bost. Consult. Gr. Available online: https: //www.bcg.com/publications/2017/industry-4.0-lean-manufacturing-five-lessons-frontlines (accessed on 7 December 2020).

64. Catlin, T.; Lorenz, J.-T.; Sternfels, B.; Willmott, P. A Roadmap for a Digital Transformation; McKinsey Co. Available online: https://www.mckinsey.com/industries/financial-services/our-insights/a-roadmap-for-a-digital-transformation (accessed on 27 October 2021).

65. Schroeck, M.; Kwan, A.; Kawamura, J.; Stefanita, C.; Sharma, D. Digital Industrial Transformation in the Age of Industry 4.0. Deloitte Insights. Available online: https:/ /www2.deloitte.com/us/en/insights/focus/industry-4-0/digital-industrialtransformation-industrial-internet-of-things.html (accessed on 27 October 2021).

66. Angevine, C.; Keomany, J.; Thomsen, J.; Zemmel, R. Implementing a Digital Transformation at Industrial Companies; McKinsey, Co. Available online: https://www.mckinsey.com/industries/advanced-electronics/our-insights/implementing-a-digitaltransformation-at-industrial-companies (accessed on 27 October 2021).

67. Industry 4.0—Self Assessment. Available online: https://i40-self-assessment.pwc.de/i40/landing/ (accessed on 5 October 2021).

68. Industrie 4.0-Readiness-Check. Available online: https://www.industrie40-readiness.de/?lang=en (accessed on 5 October 2021).

69. De Carolis, A.; Macchi, M.; Negri, E.; Terzi, S. Guiding Manufacturing Companies Towards Digitalization A methodology for supporting manufacturing companies in defining their digitalization roadmap. In Proceedings of the 23rd International Conference on Engineering, Technology and Innovation, ICE/ITMC, Madeira Island, Portugal, 27-29 June 2017; pp. 487-495. [CrossRef]

70. Hammer, M. Ops 4.0: The Human Factor-Building Ops 4.0 Capabilities. McKinsey Co. Available online: https:/ /www.mckinsey. com/business-functions / operations / our-insights/operations-blog/ops-40-the-human-factor-building-ops-40-capabilities (accessed on 20 December 2020).

71. Checkland, P. Achieving 'Desirable and Feasible' Change: An Application of Soft Systems Methodology. J. Oper. Res. Soc. 1985, 36, 821-831. [CrossRef] 
72. European Commission. Enabling Technologies for Industry 5.0-Publications Office of the EU. Available online: https: //op.europa.eu/en/publication-detail/-/publication/8e5de100-2a1c-11eb-9d7e-01aa75ed71a1/language-en (accessed on 18 November 2021).

73. European Commission. Industry 5.0: Towards more Sustainable, Resilient and Human-Centric Industry. Available online: https: / / ec.europa.eu/info/news/industry-50-towards-more-sustainable-resilient-and-human-centric-industry-2021-jan-07_en (accessed on 18 November 2021). 